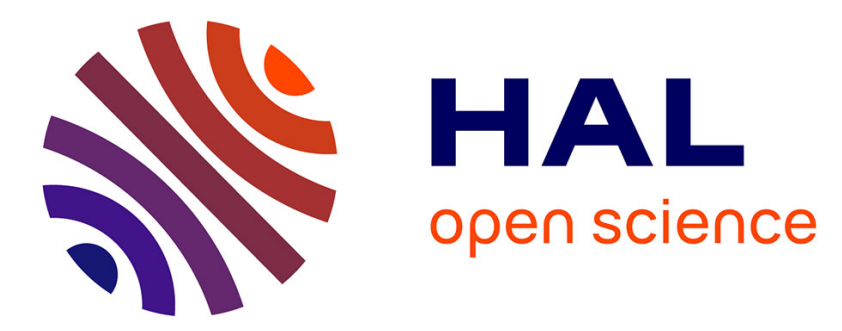

\title{
Constraining magma sources using primitive olivine-hosted melt inclusions from Puñalica and Sangay volcanoes (Ecuador)
}

Diego Narvaez, Estelle F. Rose-Koga, Pablo Samaniego, Kenneth T. Koga, Silvana Hidalgo

\section{To cite this version:}

Diego Narvaez, Estelle F. Rose-Koga, Pablo Samaniego, Kenneth T. Koga, Silvana Hidalgo. Constraining magma sources using primitive olivine-hosted melt inclusions from Puñalica and Sangay volcanoes (Ecuador). Contributions to Mineralogy and Petrology, 2018, 173 (80), 10.1007/s00410-018-1508-8 . hal-01962618

\section{HAL Id: hal-01962618 \\ https://hal.uca.fr/hal-01962618}

Submitted on 26 Nov 2020

HAL is a multi-disciplinary open access archive for the deposit and dissemination of scientific research documents, whether they are published or not. The documents may come from teaching and research institutions in France or abroad, or from public or private research centers.
L'archive ouverte pluridisciplinaire HAL, est destinée au dépôt et à la diffusion de documents scientifiques de niveau recherche, publiés ou non, émanant des établissements d'enseignement et de recherche français ou étrangers, des laboratoires publics ou privés. 
$6 \quad{ }^{1}$ Instituto Geofísico, Escuela Politécnica Nacional, Ladrón de Guevara E11-253, Aptdo. 2759, Quito, Ecuador

$7{ }^{2}$ Université Clermont Auvergne, CNRS, IRD, OPGC, Laboratoire Magmas et Volcans, F-63000 Clermont-Ferrand, 8 France

9

10 Corresponding author: Diego F. Narvaez (dnarvaez@igepn.edu.ec; ORCID ID: 0000-0003-1902-2472)

11

12 Abstract

Key words: Melt inclusions, olivine, primary magmas, volatile elements, subduction zone, Ecuador. 


\section{Introduction}

Theoretical and experimental studies on dehydration and melting reactions which occur during subduction have identified two different slab components (e.g. Elliott 2003; Kessel et al. 2005; Spandler and Pirard 2013). On the one hand, the dehydration of the subducted slab produces a low-density aqueous phase (hereafter called "fluid"), which is characterized by enrichment in large-ion lithophile elements (LILE, e.g. B, $\mathrm{Rb}, \mathrm{Ba}, \mathrm{Pb}$ ) coupled with low concentrations of high-field strength elements (HFSE, e.g. Nb, Ta, Zr) and heavy rare earth elements (HREE, e.g. Yb and Y). On the other hand, the partial melting of the subducted slab (i.e. the altered oceanic crust and/or the sedimentary cover) produces a high-density hydrous siliceous phase (hereafter called "melt"), which is enriched in the so-called fluidimmobile elements, such as the light rare earth elements (LREE, e.g. La, Ce), HFSE (e.g. Nb), as well as some LILE (e.g. Be, Th). These fluids and/or melts percolate into the hotter and shallower mantle wedge, decreasing its solidus temperature and triggering its partial melting via a porous flow process (Grove et al. 2012). Hence, the trace element signature of primitive arc magmas is typically ascribed to the nature of the subduction component (fluid or melt; e.g. Elliott et al. 1997; Class et al. 2000; Labanieh et al. 2012), whereas its major element composition is mainly controlled by the mineralogy of the mantle wedge (e.g. Grove et al. 2002).

The dichotomy between fluids and melts issued from the subducted slab was corroborated by numerical models of the thermal regime of subduction zones around the world (e.g. Syracuse et al. 2010). These models take into account the geodynamic parameters of subduction systems (age and geometry of the slab, convergence rate, etc.) as well as a temperature- and stress-dependent mantle rheology, yielding large temperature variations at the slab-mantle wedge interface. In some cases, such as Cascadia, Mexico, or the Andean Colombia-Ecuador subduction systems, the estimated temperatures are high enough to confirm the partial melting hypothesis of the subducted sediments and the altered oceanic crust (Syracuse et al. 2010; Gomez-Tuena et al. 2011; Wallowski et al. 2015). The Ecuadorian segment of the Andean Northern Volcanic Zone (NVZ) represents a unique place to test the influence of subduction parameters on the thermal regime and thus the slab component signature of primitive arc magmas. In fact, the Ecuadorian volcanic arc is characterized by an along-arc change in both the subduction parameters (age and geometry, Yepes et al. 2016), and the geochemical signature of the eruptive products (Hidalgo et al. 2012; Ancellin et al. 2017), suggesting that the thermal regime is probably not the same along the length of of the arc from north to south.

In this work, we identify the nature of the mantle source that melts to produce the primitive magmas of the Ecuadorian arc and the characteristics of the slab components added to this source. In order to fulfill these objectives, 
we focused on the southern part of the Ecuadorian arc. This choice was based on two main reasons: first, this part of the Andean NVZ is developed above a young oceanic crust to the north, which is separated from an older oceanic crust located at the southern termination of the NVZ. Secondly, given that the differentiation processes (e.g. fractional crystallization, crustal assimilation, magma mixing, etc.) obscure the composition of the primitive magmas, the study of magma sources and slab components should be restricted to the most primitive lavas displaying a high Mg\# (e.g. Kelemen et al. 2014). These kind of primitive magmas are common in the southern part of the Ecuadorian arc, namely at Punalica and Sangay volcanoes. We sampled the most primitive rock of the whole Andean NVZ in this part of the arc, which is also one of the most primitive samples of the entire Andean arc (e.g. the SAN20B basalt from Sangay volcano, Monzier et al. 1999).

Several regionally oriented whole-rock geochemical studies have investigated the Ecuadorian arc magmatism (Barragan et al. 1998; Bourdon et al. 2003; Garrison and Davidson 2003; Bryant et al. 2006; Chiaradia et al. 2009; Samaniego et al. 2010; Hidalgo et al. 2012; Ancellin et al. 2017). In this contribution, and following the melt inclusion (MI) work of Le Voyer et al. (2008) on volcanoes from the northern part of the Ecuadorian arc (Pichincha and Pan de Azúcar), we performed a similar approach by analyzing the major, trace element and volatile contents of a group of selected MIs trapped in the Mg-rich olivines hosted in primitive lavas from the southern part of the Ecuadorian arc (Puñalica and Sangay volcanoes). This work enabled us to constrain the mantle and slab components of the most primitive magmas studied in the NVZ and to relate them to the particular geodynamical setting of this part of the Andean arc. In addition, the new Sangay melt inclusion data represent a new example of primitive, Ca-rich, Nenormative melt inclusions in a context of a volcanic arc constructed on a thick continental crust.

\section{Geodynamical and geological context}

\section{Geodynamical setting of the Ecuadorian Andes}

The Northern Volcanic Zone (NVZ) of the Andes stretches from $\sim 6^{\circ} \mathrm{N}$ to $\sim 2^{\circ} \mathrm{S}$ along the cordilleras of Colombia and Ecuador, and is situated at the convergent zone where the oceanic Nazca plate plunges under the continental South American plate (Fig. 1a). In Ecuador (i.e. from $1^{\circ} \mathrm{N}$ to $\left.2^{\circ} \mathrm{S}\right)$, the relatively young Nazca plate (12-16 Ma; Gutscher et al. 1999; Sallarès and Charvis 2003) converges at an azimuth of N85 E, a rate of 5-6 cm/year (Kellogg et al. 1995) and a subduction angle of $25^{\circ}$ (Guillier et al. 2001). In addition, at these latitudes the subducting Nazca plate hosts the Carnegie ridge, a 200-250 km-wide, $2 \mathrm{~km}$-high submarine mountain range issued from the activity of the Galápagos hotspot. Based on geodynamic reconstruction, Sallarès and Charvis (2003) suggest that the portion of the Carnegie 
ridge involved in the subduction system is younger than $10 \mathrm{Ma}$. Due to its morphology, the sedimentary blanket of the subducting Carnegie ridge is relatively thin (maximum 200-400 m, Michaud et al. 2005; Proust et al. 2016). To the south (i.e. roughly to the south of 2-3 ${ }^{\circ}$ ), the subducting slab is older (25-30 Ma; Gutscher et al. 1999). The boundary between these two contrasting domains is the Grijalva Fracture Zone (GFZ), which consists of a $500 \mathrm{~m}$-high escarpment separating a "young" crust which originated in the Galápagos spreading center to the north, and a relatively "old" crust formed at the East Pacific rise to the south. The inland prolongation of this structure was recently identified by Yepes et al. (2016) in the southern part of the Ecuadorian volcanic arc (Fig. 1b). These authors also show that the slab displays a bend around the GFZ that abruptly increases the angle of subduction from $20-25^{\circ}$ to the north of the GFZ to $30-35^{\circ}$ towards the south (Yepes et al. 2016).

The Ecuadorian segment of the NVZ is characterized by at least 84 volcanic centers of Pleistocene and Holocene age, which are distributed along four principal alignments constructed over different terranes of contrasting ages and lithologies (Hall et al. 2008; Hidalgo et al. 2012). The crustal thickness is inferred to be $>50 \mathrm{~km}$ beneath the active volcanic arc (Feinenger and Seguin 1983; Prevot et al. 1996; Guillier et al. 2001). Besides the primitive nature of the Puñalica and Sangay lavas, we chose these volcanoes for this study because they are a priori constructed on slab segments with different ages and seismic characteristics (Yepes et al. 2016). Puñalica is roughly above (or immediately to the north) of the GFZ projection, while Sangay lies to the south of this boundary. We expect that the presence of the GFZ in the Ecuadorian subduction system (i) might act as a preferred fluid transport region, and (ii) should allow us to identify different slab inputs from "young" and "old" slabs into the mantle wedge.

\section{Geological context of Sangay and Puñalica volcanoes}

Sangay volcano (5230 $\mathrm{m}$ above sea level - a.s.l.) is the southernmost active edifice of the NVZ. It was constructed over the last $500 \mathrm{ka}$ by three successive edifices (Monzier et al. 1999) separated by two major sector collapses whose deposits outcrop to the east, on the upper Amazonian plain. Sangay is thought to be located $\sim 120-130 \mathrm{~km}$ (see red dotted line in Fig. 1b) above an old, seismogenic slab to the south of the GFZ (Monzier et al. 1999; Yepes et al. 2016) and is constructed on continental crust that consists of felsic and mafic igneous and metamorphic rocks (Aspden and Litherland 1992; Pratt et al. 2005). In this work, we focus on the primitive basalt (SAN20B, Mg\# 69, Monzier et al. 1999), from the Sangay II edifice, roughly dated at between 100 and 50 ka. Puñalica volcano (3988 m a.s.l.) is a 300 m-high, cone-shaped edifice slightly elongated in a north-south direction. It is constructed on the eastern flank of the Late Pleistocene Carihuairazo volcano (Ordóñez 2012). Clapperton (1990) and Ordóñez (2012) described a series of 
lava flows from Puñalica that overly a sequence of tephra fallout deposits from the neighboring Chimborazo volcano (Samaniego et al. 2012). Based on this stratigraphic information, we expect an age younger than 18-25 ka for this edifice. The depth of the subducted slab at this location is $\sim 120 \mathrm{~km}$ with the inland projection of the GFZ roughly below Puñalica volcano (Yepes et al. 2016). As for Sangay, we selected the most primitive lavas and tephras from Puñalica, which correspond to scoriaceous bombs sampled on the Puñalica cone (CAR83A, CAR96A and CAR113B), and a lava flow (RIO17A) that outcrops 4 km away from Puñalica's crater.

\section{Methodology}

Sample selection, olivine preparation and heating experiments

The chosen rocks (CAR83A, CAR96A, CAR113B, RIO17A from Puñalica, and SAN20B from Sangay volcano) were crushed and the $0.4-1.5 \mathrm{~mm}$ fraction was separated. We picked about 500 olivine crystals under a binocular microscope. We used crystal-bound to attach crystals onto glass slides in order to polish and select olivines in which melt inclusions were observed (about 100 crystals). We then selected about 50 crystals with melt inclusions bigger than $30 \mu \mathrm{m}$. All melt inclusions were crystallized and presented bubbles. Thus, we performed homogenization using a Vernadsky-type microscope heating stage following the method described by Le Voyer et al. (2010). A detailed description of melt inclusion homogenization procedure and analytical methods is provided in Online Supplementary Material 1. The data obtained for major elements by electron microprobe (EMP), volatile element concentrations by SIMS and trace element analysis by LA-ICPMS are provided in Table 1. We have taken specific care over the volatile element analysis in the MI (e.g. fluorine, chlorine) and post-analysis verifications of their quality such as the identification of misplaced beam-craters.

\section{Post-entrapment crystallization correction}

The composition of a melt inclusion can be modified by crystallization of olivine from the wall of the melt inclusion after its formation, by crystallization of minerals inside the melt inclusions during slow cooling or by overdissolution of the olivine wall during heating stages. In order to account for these effects, after homogenization of the melt inclusions, the major element compositions of the melt inclusions were corrected numerically by dissolving/adding equilibrium olivine through iterative steps, recalculating the melt composition at every step until the melt reached Fe$\mathrm{Mg}$ exchange equilibrium with the host olivine (Le Voyer et al. 2008). We used a $\mathrm{Kd}^{\mathrm{Fe}-\mathrm{Mg}}$ model to calculate the olivine 
composition added to the MI (Toplis 2005). For the model calculation, we adopted the average homogenization temperature $\left(1218 \pm 15^{\circ} \mathrm{C}\right.$, min-max temperature range of $\left.1143-1309^{\circ} \mathrm{C}\right)$ and an oxidation state calculated following Wallace and Carmichael (1992). The speciation of sulfur was measured using the $\mathrm{S}^{2-}$ and $\mathrm{S}^{6+}$ peak positions in the melt inclusions obtained by the electron microprobe (Jugo et al. 2005). The $\mathrm{Fe}^{+3} / \sum \mathrm{Fe}$ ratios for Puñalica melt inclusions vary from 0.16 to 0.23 , while for Sangay the ratio is 0.28 for all melt inclusions (Table A1, Online Supplementary Material 1). The resulting post-entrapment olivine crystallization correction for most melt inclusions was less than $10 \%$, except for "BC" and "K" melt inclusions that reach 17 and $22 \%$ respectively. In spite of the large corrections for these two MIs, we kept them in our database because their compositions are coherent with the others and thus they do not change our conclusions.

\section{Results}

Whole-rock petrological background of Sangay and Puñalica

Sangay samples display a high-K calc-alkaline magmatic series spanning from basaltic andesites to dacites (53.668.1 wt.\% $\mathrm{SiO}_{2}$, Fig. 2) and include a primitive basalt (SAN20B) that plots at lower silica content than the whole Sangay series (Fig. 2, 3). This latter is the most primitive basalt that has so far been sampled in the NVZ (Monzier et al. 1999) with 50.3 wt.\% $\mathrm{SiO}_{2}, 11.1$ wt.\% $\mathrm{MgO}$, and a $\mathrm{Mg} \#$ of 69 (Fig. 2, 3; Table 2). The high $\mathrm{Ni}$, and $\mathrm{Cr}$ contents $(273$ ppm Ni, 410 ppm Cr) and the relatively low $\mathrm{Al}_{2} \mathrm{O}_{3}$ concentration (14.8 wt.\%) corroborate its primitive character. The trace element abundances in SAN20B basalt show a typical arc pattern (e.g. enriched LREE and LILE, negative HFSE anomaly) and consistently plot at the primitive end of the Sangay series. It is worth noting that the $\mathrm{Nb}$ content in SAN20B basalt is slightly higher than that of the other NVZ basalts and basaltic andesites. Monzier et al. (1999) interpreted this feature as the result of partial melting of a relatively enriched mantle source. SAN20B mineralogy consists of phenocrysts of Mg-rich olivine ( $7 \mathrm{vol} \%$; up to $1 \mathrm{~mm}$ ), and euhedral clinopyroxene (3 vol.\%, 0.4-0.5 mm) surrounded by an intersertal groundmass consisting of clinopyroxene and plagioclase microlites. Olivine phenocrysts frequently include Cr-rich spinel inclusions. The Mg-rich olivines (Fo86-90) from this sample were selected for this study.

Puñalica lavas are medium-K calc-alkaline basaltic andesites and andesites (54.6-60.1 wt.\% $\mathrm{SiO}_{2}$, Fig. 2, 3; Table 2), including some primitive andesites characterized by $\mathrm{Mg} \#>60$. On the basis of the $\mathrm{MgO}$ content, two groups are identified. A first group includes samples with low silica content (up to $57 \mathrm{wt} . \% \mathrm{SiO}_{2}$ ) and variable $\mathrm{MgO}$ concentrations (4.3-7.8 wt.\%), and a second group includes more differentiated magmas (58-60 wt.\% $\mathrm{SiO}_{2}$ ) and homogeneous $\mathrm{MgO}$ 
contents (4.8-6.2 wt.\%). It is worth noting that the first group display large incompatible elements variations, namely for LREE (e.g. 15-35 ppm La) and LILE (4-9 ppm Th). The selected Puñalica samples correspond to both groups (Fig. 2, 3; Table 2). They show variable phenocryst abundances of olivine (Fo80-86), orthopyroxene, clinopyroxene and plagioclase surrounded by an intersertal groundmass that includes plagioclase and clinopyroxene microlites. Olivine (up to 7 vol.\%, up to $1 \mathrm{~mm}$ ) forms euhedral and subhedral phenocrysts with homogeneous compositions.

\section{Melt inclusion compositions}

\section{Major elements}

Olivine-hosted (Fo86-89, Fig. 4a) melt inclusions from Sangay volcano are nepheline-normative (from 14.9 to 21.1, $\mathrm{Ne}$, Table 1) and are characterized by restricted concentrations in $\mathrm{SiO}_{2}$ (from 41.9 to $44.5 \mathrm{wt} . \%$, expressed in a volatilefree basis, Fig. 3), $\mathrm{MgO}$ (6.4-9.1 wt.\%) and $\mathrm{FeOt}$ (7.7-10.6 wt.\%), as well as homogeneous $\mathrm{Mg \#}$ values ranging from 59 to 64 (Fig. 3, 4b). Sangay MIs mostly plot in the basaltic field belonging to a shoshonitic series (Fig. 2). In most Harker diagrams, Sangay MI compositions do not form an extension of the whole-rock trend (Fig. 3), showing higher contents in $\mathrm{Al}_{2} \mathrm{O}_{3}, \mathrm{CaO}$ and $\mathrm{TiO}_{2}$ than their host lava. Sangay MI represent, together with Pan de Azúcar melt inclusions studied by Le Voyer et al. (2008), the most $\mathrm{SiO}_{2}$-poor magmas found in the Ecuadorian volcanic arc. Olivine-hosted (Fo82-86, Fig. 4a) melt inclusions from Puñalica display high-K calc-alkaline basaltic to basaltic andesitic compositions (Fig. 2), which are characterized by a variable content of $\mathrm{SiO}_{2}$ (from 46.3 to 56.2 wt.\%), $\mathrm{MgO}$ (3.9-10.2 wt.\%) and FeOt (5.415.2 wt.\%) (Fig. 3). The Mg\# values vary from 53 to 58 (Fig. 4). As at Sangay, Puñalica MI have lower $\mathrm{SiO}_{2}$ contents than Puñalica whole-rocks and do not form a continuous trend with them. Puñalica MI show higher contents of $\mathrm{K}_{2} \mathrm{O}$, $\mathrm{Na}_{2} \mathrm{O}, \mathrm{FeOt}$ and lower contents of $\mathrm{TiO}_{2}$ and $\mathrm{CaO}$ than the values expected from the whole-rock trend at the same $\mathrm{SiO}_{2}$ content (Fig. 2 and 3).

\section{Trace and volatile elements}

Sangay MI show trace element patterns typical of arc lavas and similar to those of Puñalica MI, except for the relatively high values of Ti and HFSE (e.g. Ta, Nb), expressed as a less marked negative anomaly in Nb (Fig. 5). The trace element patterns are also similar to those displayed by Sangay whole-rocks. Sangay MI have $(\mathrm{La} / \mathrm{Yb})_{\mathrm{N}}$ values ranging from 7 to 15 (normalized to primitive mantle, Sun and McDonough 1989). Puñalica MI are also enriched in LILE (e.g. Ba, K, Rb, Sr) and depleted in HREE (e.g. Yb) relative to MORB. The enrichment in LREE (e.g. La) relative 
to HREE is represented as $(\mathrm{La} / \mathrm{Yb})_{\mathrm{N}}$ and ranges from 5 to 45 . These MI also display a marked negative anomaly in HFSE (e.g. Nb, Fig. 5). Three different MI groups are distinguished at Puñalica volcano based on trace and volatile elements concentrations (see below).

Sangay MI are volatile-rich, with $\mathrm{H}_{2} \mathrm{O}$ between 2.6 and 3.2 wt.\% and $\mathrm{CO}_{2}$ between 2776 and 6088 ppm. Puñalica melt inclusions vary from 0.05 wt. $\%$ to 3.1 wt. $\% \mathrm{H}_{2} \mathrm{O}$ and from 29 to $4307 \mathrm{ppm} \mathrm{CO}_{2}$ (Table 1). $\mathrm{H}_{2} \mathrm{O}$ concentrations measured in melt inclusions are considered as minimum values because melt inclusions are leaky containers for $\mathrm{H}_{2} \mathrm{O}$ (Chen et al. 2011; Gaetani et al. 2012). $\mathrm{CO}_{2}$ concentrations are also considered minimum because melt inclusions could suffer from pre-entrapment $\mathrm{CO}_{2}$ degassing due to degassing of $\mathrm{CO}_{2}$ from the magma at depth.

Sangay MI are characterized by relatively high S concentrations (3836-5473 ppm), which overlap with the S concentrations of some Puñalica MI (most of them from CAR113B, Table 1). Melt inclusions from RIO17A have less S, between 2310 and 4335 ppm, with two inclusions more degassed in S at 906 and 1457 ppm. Samples from CAR83A have the least S (between 609 and 1571ppm). The total range of S contents in melt inclusions from Sangay and Puñalica (609-5479 ppm) is similar to that of melt inclusions from other continental subduction zones such as Colima, Mexico (400-4900 ppm S; Vigouroux et al. 2008) and Mt. Shasta, California (in melt inclusions from High Alumina Olivine Tholeite, HAOT: 842-4800 ppm S; Le Voyer et al. 2010). Sangay MI are richer in F (627-1183 ppm) than melt inclusions from Puñalica (samples CAR96A, RIO17A and CAR83A, 439-1008 ppm, Table 1). Cl is the most contrasted volatile element. Sangay and Puñalica CAR83A melt inclusions have low and similar Cl concentrations (1636-2257 ppm and 1352-1948 ppm, respectively), while all other Punalica MI are Cl-rich, with concentrations between 4021$6112 \mathrm{ppm}$ (Table 1). The $\mathrm{Cl}$ compositions of Sangay and most Puñalica MI are extremely high (maximum $6112 \mathrm{ppm}$ Cl), only exceeded by rare melt inclusions ( $<9000 \mathrm{ppm}$ ) from Izu (Straub and Layne 2003), Aeolian (Métrich et al. 1993, 2004; Vaggelli et al. 1993; Clocchiatti et al. 1994; Schiano et al. 2004; Spilliaert et al. 2006; Collins et al. 2009; Rose-Koga et al. 2012; Sorbadère et al. 2013) and Vanuatu arcs (Sorbadère et al. 2011; 2013). F concentrations are the highest found in arc melt inclusions to date. Overall, the halogen compositions ( $\mathrm{F}$ and $\mathrm{Cl})$ of the Sangay and Puñalica melt inclusions are high for continental arc settings, in the same range as that of the melt inclusions from the HAOT of Mt. Shasta, while Puñalica melt inclusions have the highest $\mathrm{Cl}$ concentrations so far reported for this type of geodynamic setting.

\section{Classification of Puñalica melt inclusion groups}


Based on the description of the chemical compositions of the Punalica melt inclusions, we have defined three different groups. All these melt inclusions are trapped in $\mathrm{Fo}>82$ olivines and most of them have a lower $\mathrm{SiO}_{2}$ content than the host lavas.

Group 1 have the highest $\mathrm{SiO}_{2}$ and the lowest $\mathrm{MgO}$ and $\mathrm{FeOt}$ contents and plot close to the trend drawn by the wholerocks in Harker and trace element diagrams (Fig. 3 and 5). Group 1 consists of four MI found in sample CAR83A, which have similar trace element patterns to those of the whole-rocks, and the lowest LREE (e.g. La, Ce) values normalized to primitive mantle (Fig. 5). They are trapped in Fo83-84 olivines. Their $(\mathrm{La} / \mathrm{Yb})_{\mathrm{N}}$ values vary from 5 to 14. Group 1 is also characterized by the lowest contents of $\mathrm{Cl}(1350-1950 \mathrm{ppm}), \mathrm{F}$ (439-560 ppm) and S (610-1570 ppm) compared to other groups of MI from Puñalica.

Group 2 has similar compositions to Group 3 for $\mathrm{FeOt}, \mathrm{MgO}$ and $\mathrm{SiO}_{2}$. Group 2 consists of twenty-six MI from CAR113B and RIO17A samples. Group 2 MI are enclosed in Fo84 olivines. This group of MI show intermediate Cl (4037-6112 ppm) and $\mathrm{F}(483-1000 \mathrm{ppm})$ contents and $(\mathrm{La} / \mathrm{Yb})_{\mathrm{N}}$ values that vary from 9 to 25 . A marked difference between CAR113B and RIO17A MI is the elevated S content, as CAR113B MI contains 1635 to 6738 ppm S and RIO17A from 906 to 4335 ppm S.

Group 3 is depleted in $\mathrm{Al}_{2} \mathrm{O}_{3}$ (Fig. 3) and enriched in trace elements compared to Groups 1 and 2. Group 3 consists of twelve MI from CAR96A. The olivine crystals are Fo83. Group $3 \mathrm{MI}$ are characterized by high $(\mathrm{La} / \mathrm{Yb})_{\mathrm{N}}$ values that vary from 13 to 45, high Sc (up to 46 ppm, Groups 1 and 2 up to 23 ppm), high F (from 596 to 2187 ppm) and similar $\mathrm{Cl}$ (3460-5985 ppm) contents to those of Group 2. Moreover, Group 3 MI have LREE primitive mantle-normalized values (e.g. La, Ce), higher than the Puñalica whole-rocks (Fig. 5). Group 3 has the highest F concentrations (even compared to Sangay melt inclusions), all between 922 and 2187 ppm, except for one MI at 596 ppm (Table 1).

\section{Discussion}

\section{Magmatic processes prior to entrapment}

Melt inclusions may record dissolution-reaction-mixing (DRM) processes within the magmatic plumbing system (Danyushevsky 2004). These types of inclusions are commonly trapped in Fo>85 olivines, and are numerous, often clustered in single crystals and are due to rapid crystallization. Such characteristics differ significantly from those of our samples. Puñalica and Sangay melt inclusions are trapped in primitive olivines, and the melt compositions are independent of the Fo content of the host crystal. Melt inclusions in our samples were scarce, and we never found 
groups of melt inclusions in the same crystal as reported by Danyushevsky (2004). Based on these textural and compositional characteristics, the melt inclusions represent a primary inclusion character that formed at the time of the first growth of olivine. Thus, the compositions of the melt inclusions reported here have captured primitive melts that are different from host lavas. Our homogenization procedure and post-entrapment crystallization correction closely reconstitutes such primitive melt compositions at the time of capture, except for the abundance of $\mathrm{H}_{2} \mathrm{O}$ and $\mathrm{CO}_{2}$ (which must be considered as minimum values).

\section{Primitive magmas determined from melt inclusions}

\section{Assessment of post-entrapment modifications}

Puñalica and Sangay melt inclusions are trapped in Fo82-86 and Fo86-89 olivines respectively. Compositional corrections for post-entrapment crystallization and degassing of melt inclusions are viable only for inclusions efficiently isolated from the influence of the external magma surrounding the host olivine. In fact, the composition of melt inclusions in readily exchanged major elements is susceptible to irreversible, post-entrapment modifications. Specifically, the host olivine can continuously exchange Fe and Mg with the surrounding magma, potentially leading to "Fe-loss" when comparing the melt inclusion composition to that of the whole-rock. Therefore, the exact reconstruction of the $\mathrm{FeO}$ and $\mathrm{MgO}$ contents of the parental magma cannot be achieved (Danyushevsky et al. 2000; Gaetani and Watson 2000; Danyushevsky 2002). However, most MI extend the whole-rock trend towards low silica compositions (excepting those from Puñalica Group 1 and Z, T and U from Group 2, Table 1), thus it seems reasonable to postulate that Fe-Mg exchange is limited. Other species, such as $\mathrm{H}^{+}$in melt inclusions, can also re-equilibrate with an external melt through the host olivine crystal and therefore the $\mathrm{H}_{2} \mathrm{O}$ contents of melt inclusions represent minimum $\mathrm{H}_{2} \mathrm{O}$ values and do not systematically represent either the initial $\mathrm{H}_{2} \mathrm{O}$ concentrations at the time of entrapment or the primitive $\mathrm{H}_{2} \mathrm{O}$ abundance (Chen et al. 2011; Gaetani et al. 2012, 2014). Melt inclusions from this study are therefore considered as representative of minimum $\mathrm{H}_{2} \mathrm{O}$ concentrations of Punalica and Sangay magmas and we will not use them in the rest of the discussion. Because trace elements (e.g. the rare earth elements) diffuse significantly more slowly than $\mathrm{H}^{+}, \mathrm{Fe}$, and Mg (Cherniak 2015), abundances of such elements should closely resemble those at the time of entrapment following the crystallization correction (see section on post-entrapment crystallization correction in the supplementary material). Thus, the ratios of incompatible trace elements remain unmodified, as they are not partitioned into olivine, and are therefore representative of the primitive parental magma. 
A petrogenetic decoupling between olivine-hosted melt inclusions and the host eruptive products (lavas and tephra) is clearly seen in Harker diagrams (Fig. 3). If the parental magma of the erupted products crystallized the olivines (with their inclusions), as it crossed the liquidus, the melt inclusion and lava/tephra compositions should plot along the olivine-controlled liquid line of descent (Fig. 3). We show the liquid line of descent calculated with R-MELTS algorithm (Gualda et al. 2015) from the more primitive MI compositions for both Puñalica (solid line) and Sangay (dashed line) magmatic suites, with a fixed pressure of $400 \mathrm{MPa}$, a $f \mathrm{O}_{2}$ at $\mathrm{NNO}$ and 4 wt. $\% \mathrm{H}_{2} \mathrm{O}$. The liquid-line-ofdescent curves, for higher pressure values (i.e. $800 \mathrm{MPa}$, not shown), would display similar results. In fact, given that the first crystallization stages of Puñalica and Sangay MI are mainly controlled by olivine fractionation, there are almost no changes with pressure. Therefore, the Puñalica and Sangay host eruptive products cannot be derived from their respective melt inclusions by either simple olivine or olivine + clinopyroxene + plagioclase fractionation.

The projection from olivine into a Di-Ne-Q ternary plot (Fig. 6) yields additional constraints on the genesis of these MI. This projection from the olivine apex allows us to avoid any correction effect or chemical exchange between the melt inclusion and the host olivine (e.g. Sorbadère et al. 2013a, b). When plotted on the Di-Ne-Q plane, the studied Puñalica whole-rock samples are hypersthene-normative, whereas most of the 42 olivine-hosted (Fo82-86, Fig. 4a) melt inclusions from Puñalica volcano are nepheline normative (up to $10.1 \mathrm{Ne}$, Table 1); only six (AA, AC, AG1, K, S1 and BB) are hypersthene normative. Sangay whole-rock (SAN20B) and melt inclusions are all nepheline normative (Fig. 6). Magma compositions of low pressure crystallization sequences (especially at anhydrous conditions) cannot plot across the boundary separating nepheline and hypersthene normative magmas, which is defined by the Di-An join (Fig. 6). Typical mineral phases crystallizing from a basaltic magma $(\mathrm{ol}+\mathrm{cpx}+\mathrm{plg})$ define a Fo-Di-An plane, which is projected on the Di-Ne-Q plane as a line joining Di-An, and magmas plotting to the left of the line can only evolve further to the left with crystallization, and vice-versa for the right. Occurrence of these Ca-rich, Ne-normative primitive melts in continental arcs, like at Sangay, are scarce and so far have only been reported at Mt. Shasta, Cascades (Le Voyer et al. 2010), Vulcano, Italy (Gioncada et al., 1998; Rose-Koga et al. 2012), Ambrym and Gaua, Vanuatu (Sorbadère et al. 2013a, b), Grenada and St Vincent, Lesser Antilles (Bouvier et al. 2010), Batan, Philippines (Métrich et al. 1999), Lombok, Indonesia (Elburg et al. 2007) and Pan de Azucar and Pichincha, Ecuador (Le Voyer et al. 2008).

An alternative process to evolve magmas from the nepheline to hypersthene normative fields is fractional crystallization of silica-undersaturated minerals. For instance, amphibole crystallization can significantly increase the silica content in the residual liquid, eventually causing it to cross the nepheline-hypersthene divide (e.g. Frezzotti 2001). 
It is possible to examine whether or not such processes are responsible for deriving the erupted lavas from the melt inclusion compositions by investigating trace element abundances and their variations. Because amphibole preferentially incorporates $\mathrm{Dy}$ over $\mathrm{Yb}$ and $\mathrm{La}$, the role of amphibole during differentiation is illustrated by a $\mathrm{La} / \mathrm{Yb}$ increase and a decrease in $\mathrm{Dy} / \mathrm{Yb}$ during differentiation (Davidson et al. 2007). The $\mathrm{Dy} / \mathrm{Yb}$ (not shown) is highly variable in all $\mathrm{MI}$ and does not form a clear negative correlation with $\mathrm{SiO}_{2}$. In addition to REE systematics, other observations argue against a role of amphibole fractionation in these inclusions. Significant amphibole fractionation is not expected in a basalt or primitive andesite at high temperature (e.g. Krawczynski et al. 2012) such as that recorded in the inclusions $\left(\mathrm{T}_{\text {homogenization }}=1218^{\circ} \mathrm{C}\right)$.

In conclusion, these observations indicate that the melts trapped in olivine crystals are not the parental magmas of the erupted lavas. Puñalica and Sangay melt inclusions represents primitive melts that are not related to host eruptive products, extending the magmatic series towards low silica contents.

Mantle sources for Puñalica and Sangay primitive magmas

Experimental studies have striven to characterize the different lithologies melting under arcs (see Fig. 6 caption for references). The experimentally-determined fields for magma compositions issued from melting of different mantle lithologies (peridotite, pyroxenite) are reported in Fig. 6 for pressures between 0.5 and $3.5 \mathrm{GPa}$ (see figure caption for references). Puñalica melt inclusions plot in the field of peridotite melts (dotted field in Fig. 6) for different pressures. Group 1 and Group 2 MI have compositions similar to peridotite-melts coming from lower pressures (up to 2 GPa; Fig. 6) than Group 3 (up to $3.5 \mathrm{GPa}$ ). Such a discrepancy is mainly due to lower $\mathrm{Al}_{2} \mathrm{O}_{3}$ contents of Group $3 \mathrm{MI}$ (Fig. 3c, Fig. 7), which is in agreement with peridotite melting experiments (e.g. Walter 1998). These experiments have shown that garnet stability increases with pressure, reducing the $\mathrm{Al}_{2} \mathrm{O}_{3}$ content in the partial melt. The stability of garnet in Group 3 $\mathrm{MI}$ is also shown by an increase in $\mathrm{La} / \mathrm{Yb}$ when $\mathrm{Al}_{2} \mathrm{O}_{3}$ decreases, creating a negative correlation (Fig. 7). Therefore, the chemical differences recorded by the Ne-normative Puñalica MI could be explained by variable depths of partial melting and thus the mineralogy of the mantle, with garnet probably present in Group $3 \mathrm{MI}$ and spinel/plagioclase for Group 1 and 2 sources, implying a deeper origin for Group 3 compared to Groups 1 and 2.

The Sangay MI plot in the field of amphibole-bearing clinopyroxenite-derived melts (Fig. 6) occurring at pressures lower than $1.5 \mathrm{GPa}$ and temperatures between $1200-1300^{\circ} \mathrm{C}$ (Médard et al. 2006). The homogenization temperature of Sangay MI varies from 1189 to $1254^{\circ} \mathrm{C}$ and is therefore in good agreement with the temperatures stipulated for amphibole-bearing clinopyroxenite-derived melts. The high $\mathrm{CaO}$, relatively high $\mathrm{FeOt}$, low silica contents and high $\mathrm{Sc}$ 
contents (from 26 to $43 \mathrm{ppm}$, Table 1) of Sangay MI, are also in agreement with compositions coming from the partial melting of an amphibole-bearing clinopyroxenite lithology. In fact Sorbadère et al. (2013) proposed that compositions similar to those of Sangay MI could be produced by mixing between partial melts of amphibole-bearing clinopyroxenite and peridotite. The compositions of the Sangay MI correspond to an end-member of the amphibole-bearing clinopyroxenite-derived melt. Similar Ca-rich, Ne-normative melt inclusions from Pan de Azúcar volcano, located in the back-arc of the Ecuadorian Arc, were also interpreted as the result of melting of pyroxenite-rich lithologies (Le Voyer et al. 2008).

The presence of clinopyroxenitic lithologies in arc sources has been widely discussed in the literature (e.g. Schiano et al. 2000; Médard et al. 2006; Sorbadère et al. 2013a, b). Clinopyroxenite is probably found in the lower crust since the differentiation process of primitive basalt produces ultramafic cumulates (i.e. clinopyroxenites), allowing the magma to evolve toward andesitic compositions (e.g. Greene 2006; Blatter et al. 2013; Nandeckar et al. 2014). These ultramafic cumulates react with new ascending hydrous magmas triggering amphibole crystallization at the expense of clinopyroxene (Smith 2014), producing the amphibole-bearing clinopyroxenites. Then, the amphibole-bearing clinopyroxenite is melted when a new hot primitive magma $\left(\mathrm{T}>1100^{\circ} \mathrm{C}\right)$ ascends through the clinopyroxenite. Alternatively, the amphibole-bearing clinopyroxenite delaminates and sinks into the hotter mantle wedge (Smith 2014; Jagoutz and Kelemen 2015; Schmidt and Jagoutz 2017). The lower solidus temperature and higher melt productivity of pyroxenites (Hirschmann and Stolper 1996) would promote olivine growth and enable entrapment of amphibole-bearing clinopyroxenite-derived melts.

\section{Constraining the slab components by trace element systematics}

Previous experimental studies have demonstrated the variable mobility of LILE, HFSE, REE and other trace elements (e.g. Li, Be) during the dehydration (low temperature) or melting (high temperature) process of the basaltic oceanic crust and/or its sedimentary cap (Kessel et al. 2005; Klimm et al. 2008; Hermann and Rubatto 2009). These studies show that aqueous fluids resulting from dehydration processes are enriched in fluid-mobile elements (e.g. Ba, $\mathrm{Rb}, \mathrm{Cs}, \mathrm{Pb}$ ) and strongly depleted in fluid-immobile elements (e.g. Be, $\mathrm{Nb}, \mathrm{La}, \mathrm{Th})$. In contrast, hydrous siliceous melts, resulting from a melting process, are enriched in both fluid-mobile and fluid-immobile elements. Based on this dichotomy, fluid-mobile/fluid-immobile element ratios have been used to identify the nature of the slab components (e.g. Elliott et al. 1997; Elliott 2003). Fig. 8a, b shows plots of $\mathrm{Sr} / \mathrm{Th}$ and $\mathrm{Ba} / \mathrm{Th}$, respectively $v$ s. $(\mathrm{La} / \mathrm{Yb})_{\mathrm{N}}$ of the melt inclusions. Because the mobile/immobile element ratio (e.g. $\mathrm{Ba} / \mathrm{Th}, \mathrm{Sr} / \mathrm{Th}$ ) of the pre-metasomatized mantle wedge (i.e. 
MORB composition) is low, the addition of aqueous fluids from the slab increases this ratio. In contrast, mantle metasomatism by hydrous silicate melts does not change the ratio due to the fact that both groups of elements (fluid mobile and immobile) are transported by siliceous melts. The melt inclusions from Puñalica plot at relatively low Ba/Th values (60 to 190, average $90 \pm 34$ ) compared to the range of word-wide primitive arc magmas (Fig. 8b, dotted area). There is no significant contrast in $\mathrm{Sr} / \mathrm{Th}$ between Groups 1, 2 and 3 of Puñalica MI (Fig. 8a). However, the three Puñalica groups have distinct and relatively constant $\mathrm{Ba} / \mathrm{Th}$ ratios within each group (Fig. 8b). The combination of the low $\mathrm{Ba} / \mathrm{Th}$ and $(\mathrm{La} / \mathrm{Yb})_{\mathrm{N}}$ (values ranging from 10 to 40$)$ for Puñalica melt inclusions is characteristic of magma most likely derived from the partial melting of a source metasomatized by hydrous siliceous melts. The mean values of Group 3 MI compositions for $\mathrm{Ba} / \mathrm{La} \sim 15, \mathrm{Ba} / \mathrm{Th} \sim 66$ and $\mathrm{Th} / \mathrm{La} \sim 0.22$ contrast with the ratios obtained for Sangay MI (Ba/La 29, Ba/Th 261 and Th/La 0.11), and are in agreement with those reported by Brandt et al. (2017a) for the northern segment of Payenia volcanic field located in the Andean Southern Volcanic Zone $(\mathrm{Ba} / \mathrm{La}=16, \mathrm{Ba} / \mathrm{Th}=63$, $\mathrm{Th} / \mathrm{La}=0.25$ ) whose source is also interpreted as having been enriched by siliceous melts.

On the other hand, $\mathrm{Ba} / \mathrm{Th}$ values from Sangay melt inclusions are around three times higher than those of Puñalica (from 230 to 280 , average $261 \pm 17$ ) and $\mathrm{Sr} / \mathrm{Th}$ ratio is also high with values between 444 to 594 (Fig. 8a; Puñalica between 103 and 209). Although not exceptionally high, the higher values for both $\mathrm{Sr} / \mathrm{Th}$ and $\mathrm{Ba} / \mathrm{Th}$ in Sangay melt inclusions suggests that aqueous fluids might have metasomatized the source of Sangay. This aqueous fluid would have been enriched in fluid mobile elements such as $\mathrm{Ba}, \mathrm{Sr}, \mathrm{Pb}$. In a previous whole-rock study on Pichincha Volcanic Complex (north of the Ecuadorian arc) a threshold value of $\mathrm{Ba} / \mathrm{Th} \sim 200$ was used to distinguish magmas metasomatized by aqueous fluids $(\mathrm{Ba} / \mathrm{Th}>200)$ from hydrous siliceous melts (Samaniego et al. 2010). Based on this threshold value, the $\mathrm{Ba} / \mathrm{Th}$ ratios of Sangay melt inclusions can be taken as resulting from aqueous fluid metasomatism.

We would stress that in the whole-rock studies at the southern termination of the Ecuadorian arc, this discrimination is not evident (e.g. Ancellin et al. 2017), possibly because of the overprint by crustal contamination that has blurred the geochemical signal, whereas olivine-hosted melt inclusions are shielded from this contamination.

Modelling the metasomatized mantle source

In order to test the hypothesis that two different subduction components are injected from the slab into the mantle wedge, we performed a three-step trace element modeling procedure. Firstly, we considered the melting or dehydration of the oceanic crust for Puñalica and Sangay, respectively. Secondly, given that the sources for Puñalica and Sangay MI are different, we mixed the slab component with a depleted peridotite for Punalica and with an amphibole-bearing 
clinopyroxenite composition for Sangay. Finally, we melted these enriched source lithologies using a batch melting equation (Shaw 1970).

1. For the basalt partial melting step, we used the high-temperature experimental $\mathrm{Kd}\left(1000^{\circ} \mathrm{C}\right)$ from Kessel et al. $(2005)$ and the average composition of the Carnegie ridge basalts (Harpp et al. 2005). This step, with a melting degree set at $5 \%$ leaves an eclogitic residue. The degree of melting is imposed by the strong negative- $\mathrm{Nb}$ anomaly in the Puñalica MI. Such an anomaly is a characteristic only attained with $>1$ vol.\% of rutile in the residue and accordingly to Gaetani et al. (2008), the rutile vol. $\%$ in the residue peaks at roughly $4 \%$ of melting. Between 4 and $5 \%$ melting does not change our conclusion. For sediment melting, we used the bulk distribution coefficients given by Plank (2005), and an average composition of sediments from the Nazca plate (Plank and Langmuir 1998). We set the melting degree at a fairly low value (i.e. $8 \%$ ). The dehydration process was modeled with the same parameters as for the melting except for Kd, which was that given by Kessel et al. $(2005)$ at low temperature $\left(800^{\circ} \mathrm{C}\right)$.

2. The trace element composition of the depleted peridotite is from Workman and Hart (2005), and that of the clinopyroxenite from Smith (2014). The mixing proportion between slab fluid or melt component and the depleted source varies from 10:90 to 15:85. When the slab component is a siliceous melt, the amount of sedimentary melt relative to basaltic melt varies in a proportion of 0 to $20 \%$.

3. For Puñalica MI, the metasomatized mantle melt is $10 \%$, leaving a residue of ol:opx:cpx in a proportion of $68: 20: 12$ and a variable amount of grt (1-8 vol.\%). We used the Kds given by Halliday et al. (2005) for basaltic melts. For Sangay, the minerals in the residue after 5\% of melting are ol:cpx:hbl:sp in a proportion of 24:70:2:4. This mineral assemblage was computed by R-Melts software (Gualda et al. 2012) at $1 \mathrm{GPa}$ and 1 wt.\% $\mathrm{H}_{2} \mathrm{O}$ for an amphibolebearing clinopyroxenite composition (from Médard et al. 2006).

Results are plotted in Fig. 9 as multi-element diagrams normalized to primitive mantle values (Sun and McDonough 1989). The Puñalica modelled composition fits very well with natural MI compositions, supporting the hypothesis that the metasomatic agent beneath Puñalica is a silicate melt (Fig. 9a). For Sangay, the modeled composition shows a reasonable agreement, although some differences (e.g. $\mathrm{Rb}, \mathrm{Nb}$ ) are highly source-dependent and can be explained by the scarce trace element data for amp-bearing clinopyroxenite compositions in the literature (Fig. 9b). Lastly, given the primitive signature of SAN20B whole-rock, we also modelled its origin as a result of a hydrous fluid-metasomatized peridotite (Fig. 9c). The parameters for dehydration were similar to those of Sangay MI modelling and the source was that of a depleted mantle (Workman and Hart 2005). The mixing proportion between the slab component and the mantle 
was fixed at 15:85 and the partial melting of the mantle at $7 \%$. The relatively good fit indicates an aqueous fluid as the metasomatic agent responsible for the composition of the SAN20B olivine-hosted melt inclusions.

Constraints provided by the volatile element compositions on the nature of the slab flux in a continental subduction zone

Sangay and Puñalica MI have high concentrations of fluorine and chlorine (Fig. 10), which is typical of volcanic arcs from continental subduction (e.g. Izu, Straub and Layne 2003; Mt. Shasta, Cascades, Le Voyer et al. 2010; Vulcano, Italy and Iwate, Japan, Rose-Koga et al. 2012, 2014). Puñalica Group 3 melt inclusions display amongst the highest F contents in continental arc-related MI (up to 2187 ppm F). This high F content is accompanied by high $\mathrm{Cl}$ concentrations ( $\mathrm{Cl}$ commonly between 5000 and $6000 \mathrm{ppm}$ in Punalica MI). For comparison, an olivine-hosted melt inclusion from Reventador volcano has 3149 ppm chlorine and 549 fluorine (Samaniego et al. 2008) and Tungurahua melt inclusions have less than 1081 ppm chlorine (Myers et al. 2014).

High halogen contents in primitive arc magmas (the case of Puñalica) can be achieved by two processes (van den Bleeken and Koga 2015): (i) the subducted crust melts (rather than simply dehydrating), or (ii) the subducted crust is enriched in halogens and eventually melts/dehydrates. Thus, one explanation is that Puñalica volcano is roughly located above the Grijalva fracture zone and the higher permeability in the fracture zone enhances interactions with seawater (compared to a normal oceanic crust), thus increasing its $\mathrm{F}$ and $\mathrm{Cl}$ contents. Furthermore and because the Puñalica slab component seems to be a siliceous melt, this altered oceanic crust eventually melts driving $\mathrm{F}$ and $\mathrm{Cl}$ contents even higher (van den Bleeken and Koga 2015). Both fluorine and chlorine are incompatible in the typical mineral phases of a garnet-bearing peridotite (van den Bleeken and Koga 2015), therefore, those elements would leave the mantle during partial melting.For an amphibole-bearing source lithology, as in the case of Sangay MI, fluorine compatibility must change because this element is compatible in amphibole, whereas chlorine is not. This preference of amphibole for fluorine would affect $\mathrm{F} / \mathrm{Cl}$ ratios. Thus, Sangay $\mathrm{F} / \mathrm{Cl}$ ratios $(0.35-0.53)$ that are higher than those from Puñalica (0.11 to 0.39) could be explained by the interaction of ascending mantle-derived magma with an amphibole-bearing clinopyroxenite, likely enriched in $\mathrm{F}$ compared to $\mathrm{Cl}$.

Slab components in the geodynamic context of the continental Ecuadorian arc and beyond

The origin of the metasomatic agent in the Ecuadorian arc has long been debated in the scientific literature. Some researchers consider that the metasomatic agent of the subarc mantle wedge is an aqueous fluid issued from 
dehydration reactions of the slab (Barragan et al. 1998; Garrison and Davidson 2003; Bryant et al. 2006; Chiaradia et al. 2009). Based on the overall adakitic signature of the Ecuadorian arc, other researchers consider that the metasomatic agent is a siliceous-melt associated with slab partial melting (Bourdon et al. 2003; Hidalgo et al. 2012). In addition, some long-lived volcanic complexes of the Ecuadorian arc are characterized by a progressive variation of the trace element signature that has been interpreted as a change of the metasomatic agent throughout its evolution. This variation in whole-rock trace elements, described at Cayambe (Samaniego et al. 2002, 2005); Illinizas (Hidalgo et al. 2007), Mojanda-Fuya Fuya (Robin et al. 2009) and Pichincha (Samaniego et al. 2010), implies that the older magmas of these volcanic complexes came from a hydrous-fluid metasomatized mantle wedge, whereas the younger magmas are related to partial melting of a siliceous-melt metasomatized mantle wedge. Such a temporal evolution suggests a change from dehydration to partial melting of the slab that could be associated with an increase in the thermal regime along the slab due to the presence of the subducted Carnegie ridge (e.g. Yepes et al. 2016). In this context, the younger age and structure of the Carnegie ridge would induce an enhanced thermal gradient along the slab, which may trigger slab partial melting. This hypothesis is supported by thermal modeling studies (e.g. Syracuse et al. 2010) that estimate elevated slab-surface temperatures below the Ecuadorian arc.

In this work, we demonstrated that the subarc mantle below two of the southern Ecuadorian volcanoes is metasomatized by different slab components. The cause of such variation might be related to the geodynamical setting, where the Grijalva Fracture Zone (GFZ) sharply separates a young slab to the north from an older slab to the south. As recently pointed out by Yepes et al. (2016), this difference in age is coupled to a contrasted seismic behavior and an increase in the subduction angle: to the north of the GFZ, the slab displays low intermediary seismicity (50-150 km depth) and subducts at an angle of $20-25^{\circ}$, whereas to the south, the slab is highly seismogenic and plunges at a higher angle $\left(30-35^{\circ}\right)$. This contrasted seismic behavior could be associated with a different thermal regime on both sides of the GFZ (Yepes et al. 2016), which in turn could control the dehydration, and the melting process happening at depth.

Based on whole-rock major, trace element, and $\mathrm{Sr}-\mathrm{Nd}-\mathrm{Pb}$ isotopic signature of the Ecuadorian arc lavas, Ancellin et al. (2017) describe a N-S variation of the metasomatic agent along the entire Ecuadorian volcanic arc. They interpreted these along-arc variations as an increase of the slab input northward and southward on both sides of a divide that they placed at $0.5^{\circ} \mathrm{S}$ (i.e. at the latitude of the Carnegie ridge subduction). They concluded that the most likely process able to explain these variations is a variable influx of slab-derived fluids or melts. In the present olivine-hosted melt inclusion study, we refine the previous findings and argue that Puñalica MI come from a mantle wedge metasomatised by a hydrous siliceous melt, whereas Sangay MI are most likely produced by partial melting of a hydrous fluid metasomatized amphibole-bearing clinopyroxenite source. 
In a more general context, the singularity of Sangay melt inclusions is striking in Fig. 6 and 9. High-Ca, Nenormative primitive arc melts exist in other arc systems around the world (cf. the section on Primitive magmas determined from melt inclusions), but are not that common in continental subduction zone settings. However, whereas the crustal thickness in the previously mentioned arc systems (Cascades, Italy, Vanuatu) is around 20-30 km thick, the Ecuadorian continental arc is characterized by a very thick arc crust $(>50 \mathrm{~km})$. The influence of crustal thickness on melt compositions is not new and has already been proposed for arc lavas (e.g. Wallace and Carmichael 1992). In the case of Sangay MI, we therefore have to reconcile the amphibole-bearing clinopyroxenite source (Ca-rich, Nenormative melts), the high volatile ( $\mathrm{F}$ and $\mathrm{Cl}$ ) contents of $\mathrm{MI}$ and the high Fo of the host olivines, with the presence of a $50 \mathrm{~km}$-thick crust. One hypothesis is that melting of the amphibole-bearing clinopyroxenite happens at depth, probably at the interface between the lower crust and the upper mantle. In order to accommodate the deep origin of the MI and the required fast migration to the surface, the occurrence of trans-crustal major faults seems an important requirement.

\section{Conclusions}

Melts inclusions from Puñalica and Sangay volcanoes are Ca-rich and have mostly Ne-normative compositions.

The magmas sampled as melt inclusions are not the parental magmas of the whole-rocks but they constitute exceptional compositions that show the complexity of the processes occurring at subduction zones and the heterogeneity of the sources of primitive arc magmas.

All melt inclusions from Puñalica have major element compositions similar to experimental melts derived from peridotite. Sangay MI have homogeneous compositions and their origin is attributed to mixing processes between melts derived from peridotite (represented by the whole-rock SAN20B composition) and amphibole clinopyroxene-rich sources.

The slab component that metasomatizes the mantle source of Punalica volcano is a siliceous melt (low mobile/immobile ratios), which displays a variable enrichment in LREE. Moreover, the high content of volatiles (e.g. F, $\mathrm{Cl}$ ) is attributed to the presence of the Grijalva Fracture Zone that separates a younger and hotter oceanic crust to the north from a colder and older oceanic crust to the south. Under Sangay volcano, the melt inclusions are produced by partial melting of metasomatized (most likely by aqueous fluids) amphibole-bearing clinopyroxenite source and the relatively higher $\mathrm{F}$ compared to $\mathrm{Cl}$ is likely due to fluorine enrichment in the source linked to fluorine compatibility with amphibole. 

continental crust, and could possibly be related to the presence of major trans-crustal faults.

\section{Acknowledgments}

This research was conducted as part of Diego Narvaez's $\mathrm{PhD}$, which is financed by the Secretaría Nacional de

Educación Superior, Ciencia, Tecnología e Innovación of Ecuador (SENESCYT, Ecuador) and the ARTS program of the French Institut de Recherche pour le Developpement (IRD). It is part of a cooperation program carried out between the Instituto Geofisico, Escuela Politécnica Nacional (IGEPN), Quito, Ecuador and the IRD, through the Laboratoire Mixte International "Séismes et Volcans dans les Andes du Nord". ER-K acknowledges funding from the French INSU scientific program SYSTER. Thank you F. Van Wyk de Vries for This work also benefited from financial support from the Laboratory of Excellence ClerVolc. This is Laboratory of Excellence ClerVolc contribution ${ }^{\circ} \mathrm{XXXX}$.

\section{References}

Ancellin MA, Samaniego P, Vlastélic I, Nauret F, Gannoun A, Hidalgo S (2017) Across-arc versus along-arc Sr-Nd-Pb isotope variations in the Ecuadorian volcanic arc. Geochemistry Geophysics Geosystems 18:1163-1188. https://doi:10.1002/2016GC006679

Aspden JA, Litherland M (1992) The geology and Mesozoic collisional history of the Cordillera Real, Ecuador, Tectonophysics, 205:187-204. https://doi:10.1016/0040-1951(92)90426-7

Baker MB, Stolper EM (1994) Determining the composition of high-pressure mantle melts using diamond aggregates. Geochimica et Cosmochimica Acta 58:2811-2827

Barragan R, Geist D, Hall M, Larson P, Kurz M (1998) Subduction controls on the compositions of lavas from the Ecuadorian Andes. Earth and Planetary Science Letters 154:153-166

Blatter DL, Sisson TW, Hankins WB (2013) Crystallization of oxidized, moderately hy- drous arc basalt at mid- to lower-crustal pressures: implications for andesite genesis. Contrib. Mineral. Petrol. 166:861-886. https://doi.org/10.1007/s00410-013- 0920-3

Bourdon E, Eissen JP, Gutscher MA, Monzier M, Hall ML, Cotten J (2003) Magmatic response to early aseismic ridge subduction: the Ecuadorian margin case (South America). Earth and Planetary Science Letters 205:123-138 
Brandt FE, Holm PM, Søager N (2017a) South-to-north pyroxenite-peridotite source variation correlated with an OIBtype to arc-type enrichment of magmas from the Payenia backarc of the Andean Southern Volcanic Zone (SVZ). Contributions to Mineralogy and Petrology 172:1. https://doi.org/10.1007/s00410-016-1318-9

Brandt FE, Holm PM, Hansteen TH (2017b) Volatile (Cl, F and S) and major element constraints on subduction-related mantle metasomatism along the alkaline basaltic backarc, Payenia, Argentina. Contributions to Mineralogy and Petrology 172:48. https://doi.org/10.1007/s00410-017-1359-8

Bryant JA, Yogodzinski GM, Hall ML, Lewicki JL, Bailey DG (2006) Geochemical Constraints on the Origin of Volcanic Rocks from the Andean Northern Volcanic Zone, Ecuador. Journal of Petrology 47:1147-1175

Chen Y, Provost A, Schiano P, Cluzel N (2011) The rate of water loss from olivine-hosted melt inclusions. Contributions to Mineralogy and Petrology 162:625-636

Cherniak DJ (2015) REE diffusion in olivine. American Mineralogist 95:362-368

Chiaradia M, Müntener O, Beate B, Fontignie D (2009) Adakite-like volcanism of Ecuador: lower crust magmatic evolution and recycling. Contributions to Mineralogy and Petrology 158:563-588

Clapperton CM (1990) Glacial and volcanic geomorphology of the Chimborazo-Carihuairazo massif, Ecuadorian Andes. Transactions of the Royal Society of Edinburgh: Earth Sciences 81:91-116

Class C, Miller DM, Goldstein SL, Langmuir CH (2000) Distinguishing melt and fluid subduction components in Umnak Volcanics, Aleutian Arc. Geochemistry, Geophysics, Geosystems. doi:10.1029/1999GC000010.

Clocchiatti R, Gioncada A, Mosbah M, Sbrana A (1994) Possible deep origin of sulfur output at Vulcano (Southern Italy) in the light of melt inclusion studies. Acta Vulcanol. 5:49-53

Collins SJ, Pyle DM, Maclennan J (2009) Melt inclusions track pre-eruption storage and dehydration of magmas at Etna. Geology 37:571-574

Danyushevsky LV (2002) Melt Inclusions in Olivine Phenocrysts: Using Diffusive Re-equilibration to Determine the Cooling History of a Crystal, with Implications for the Origin of Olivine-phyric Volcanic Rocks. Journal of Petrology 43:1651-1671

Danyushevsky LV (2004) Melt Inclusions in Primitive Olivine Phenocrysts: the Role of Localized Reaction Processes in the Origin of Anomalous Compositions. Journal of Petrology 45:2531-2553

Danyushevsky LV, Della-Pasqua FN, Sokolov S (2000) Re-equilibration of melt inclusions trapped by magnesian olivine phenocrysts from subduction-related magmas: petrological implications. Contributions to Mineralogy and Petrology 138:68-83 
Davidson J, Turner S, Handley H, Macpherson C, Dosseto A (2007) Amphibole "sponge" in arc crust? Geology 35: $787-790$

Elburg MA, Kamenetsky VS, Foden JD, Sobolev A (2007) The origin of medium-K ankaramitic arc magmas from Lombok (Sunda arc, Indonesia): Mineral and melt inclusion evidence. Chem Geol 240:260-279. doi:10.1016/j. chemgeo.2007.02.015

Elliott T (2003) Tracers of the slab. In: Eiler J (ed.) Geophysical Monograph Series. Washington, D.C.: American Geophysical Union, 23-45

Elliott T, Plank T, Zindler A, White W, Bourdon B (1997) Element transport from slab to volcanic front at the Mariana arc. Journal of Geophysical Research: Solid Earth 102:14991-15019

Falloon TJ, Danyushevky LV, Green DH (2001) Peridotite melting at 1 GPa: reversal experiments on partial melt compos- itions produced by peridotite-basalt sandwich experiments. Journal of Petrology 42:2363-2390

Feininger T, Seguin MK (1983) Simple Bouguer gravity anomaly field and the inferred crustal structure of the continental Ecuador. Geology 11: 40-44

Frezzotti ML (2001) Silicate-melt inclusions in magmatic rocks: applications to petrology. Lithos 55:273-299

Gaetani GA, O’Leary JA, Koga KT, Hauri EH, Rose-Koga EF, Monteleone BD (2014) Hydration of mantle olivine under variable water and oxygen fugacity conditions. Contributions to Mineralogy and Petrology 167:965. https://doi.org/10.1007/s00410-014-0965-y

Gaetani GA, O'Leary JA, Shimizu N, Bucholz CE, Newville M (2012) Rapid re-equilibration of $\mathrm{H}_{2} \mathrm{O}$ and oxygen fugacity in olivine-hosted melt inclusions. Geology 40:915-918

Gaetani GA, Watson EB (2000) Open system behavior of olivine-hosted melt inclusions. Earth and Planetary Science Letters 183:27-41

Gaetani GA, Grove TL (1998) The influence of water on melt- ing of mantle peridotite. Contributions to Mineralogy and Petrology 131:323-346

Garrison JM, Davidson JP (2003) Dubious case for slab melting in the Northern volcanic zone of the Andes. Geology $31: 565-568$

Gioncada A, Clocchiatti R, Sbrana A, Bottazzi P, Massare D, Ottolini L (1998) A study of melt inclusions at Vulcano (Aeolian Islands, Italy): insights on the primitive magmas and on the volcanic feeding system. Bulletin of Volcanology, 60 (286-306

Gomez-Tuena A, Mori L, Goldtein SL, Pérez-Arvizu O (2015) Magmatic diversity of western Mexico as a function of metamorphic transformations in the subducted oceanic plate. Geochimica et Cosmochimica Acta 75:213-241 
Greene AR (2006) A Detailed Geochemical Study of Island Arc Crust: the Talkeetna Arc Section, South-Central Alaska. Journal of Petrology 47:1051-1093

Grove TL, Till CB, Krawczynski MJ (2012) The Role of $\mathrm{H}_{2} \mathrm{O}$ in Subduction Zone Magmatism. Annual Review of Earth and Planetary Sciences 40:413-439

Grove T, Parman S, Bowring S, Price R, Baker M (2002) The role of an $\mathrm{H}_{2} \mathrm{O}$-rich fluid component in the generation of primitive basaltic andesites and andesites from the Mt. Shasta region, N California. Contributions to Mineralogy and Petrology 142:375-396

Gualda GAR, Ghiorso MS, Lemons RV, Carley TL (2012) Rhyolite-MELTS: A modified calibration of MELTS optimized for silica-rich, fluid-bearing magmatic systems. Journal of Petrology 53:875-890

Guillier B, Chatelain JL, Jaillard E, Yepes H, Poupinet G, Fels JF (2001) Seismological evidence on the geometry of the Orogenic System in central-northern Ecuador (South America). Geophysical Research Letters 28:3749-3752

Gutscher MA, Malavieille J, Lallemand S, Collot JY (1999) Tectonic segmentation of the North Andean margin: impact of the Carnegie Ridge collision. Earth and Planetary Science Letters 168:255-270

Hall ML, Samaniego P, Le Pennec JL, Johnson JB (2008) Ecuadorian Andes volcanism: A review of Late Pliocene to present activity. Journal of Volcanology and Geothermal Research 176:1-6

Halliday AN, Lee DC, Tommasin S, Davies GR, Paslick CR, Fitton GJ, James DE (1995) Incompatible trace elements in OIB and MORB and source enrichments in the sub oceanic mantle. Earth and Planetary Science Letters 133:379395

Hermann J, Rubatto D (2009) Accessory phase control on the trace element signature of sediment melts in subduction zones. Chemical Geology 265:512-526

Hidalgo, S., Gerbe, M. C., Martin, H., Samaniego, P. \& Bourdon, E. (2012). Role of crustal and slab components in the Northern Volcanic Zone of the Andes (Ecuador) constrained by Sr-Nd-O isotopes. Lithos 132-133, 180-192

Hidalgo S, Monzier M, Martin H, Chazot G, Eissen JP, Cotten J (2007) Adakitic magmas in the Ecuadorian Volcanic Front: Petrogenesis of the Iliniza Volcanic Complex (Ecuador). Journal of Volcanology and Geothermal Research $159: 366-392$

Hirose K, Kushiro I (1993) Partial melting of dry peridotite at high pressures: determination of compositions of melts segregated from peridotite using aggregates of diamond. Earth and Planetary Science Letters 114:477-489

Hirose K, Kawamoto T (1995) Hydrous partial melting of lherzolite at $1 \mathrm{GPa}$ : The effect of $\mathrm{H} 2 \mathrm{O}$ on the genesis of basaltic magmas. Earth and Planetary Science Letters 133:463-473 
Hirschmann MM., Stolper EM (1996) A possible role for garnet pyroxenite in the origin of the "garnet signature" in MORB. Contributions to Mineralogy and Petrology 124:185-208

Hofmann AW (1988) Chemical differentiation of the Earth: the relationship between mantle, continental crust, and oceanic crust. Earth and Planetary Science Letters 90:297-314

Jaillard E, Bengtson P, Ordoñez M, Vaca W, Dhondt A, Suárez J, Toro J (2008) Sedimentary record of terminal Cretaceous accretions in Ecuador: The Yunguilla Group in the Cuenca area. Journal of South American Earth Sciences 25:133-144

Jagoutz O, Kelemen PB (2015) Role of Arc Processes in the Formation of Continental Crust. Annu. Rev. Earth Planet. Sci. $43: 12.1-12.42$

Jugo PJ, Luth RW, Richards JP (2005) Experimental data on the speciation of sulfur as a function of oxygen fugacity in basaltic melts. Geochimica et Cosmochimica Acta 69: 497-503

Kelemen PB, Hanghøj K, Greene AR (2014) One View of the Geochemistry of Subduction-Related Magmatic Arcs, with an Emphasis on Primitive Andesite and Lower Crust. Treatise on Geochemistry. Elsevier, 749-806

Kellogg JN, Vega V, Stailings TC, Aiken CL (1995) Tectonic development of Panama, Costa Rica, and the Colombian Andes: constraints from global positioning system geodetic studies and gravity. Geological Society of America Special Papers 295:75-90

Kessel R, Schmidt MW, Ulmer P, Pettke T (2005) Trace element signature of subduction-zone fluids, melts and supercritical liquids at 120-180 km depth. Nature 437:724-727

Klimm K, Blundy JD, Green TH (2008) Trace Element Partitioning and Accessory Phase Saturation during $\mathrm{H}_{2} \mathrm{O}-$ Saturated Melting of Basalt with Implications for Subduction Zone Chemical Fluxes. Journal of Petrology 49:523553

Kogiso T, Hirschmann MM (2001) Experimental study of clino- pyroxenite partial melting and the origin of ultra-calcic melt inclu- sions. Contributions to Mineralogy and Petrology 142:347-360

Krawczynski MJ, Grove TL, Behrens H (2012) Amphibole stability in primitive arc magmas: effects of temperature, $\mathrm{H}_{2} \mathrm{O}$ content, and oxygen fugacity. Contributions to Mineralogy and Petrology 164:317-339

Labanieh S, Chauvel C, Germa A, Quidelleur X (2012) Martinique: a Clear Case for Sediment Melting and Slab Dehydration as a Function of Distance to the Trench. Journal of Petrology 53:2441-2464

Lambart S, Laporte D, Schiano P (2009) An experimental study of pyroxenite partial melts at 1 and $1.5 \mathrm{GPa}$ : Implications for the major-element composition of Mid-Ocean Ridge Basalts. Earth and Planetary Science Letters 288:335-347 
Laporte D, Toplis MJ, Seyler M, Devidal JL (2004) A new experimental technique for extracting liquids from peridotite at very low degrees of melting: application to partial melting of depleted peridotite. Contributions to Mineralogy and Petrology 146:463-484

Le Voyer M, Rose-Koga EF, Laubier M, Schiano P (2008) Petrogenesis of arc lavas from the Rucu Pichincha and Pan de Azucar volcanoes (Ecuadorian arc): Major, trace element, and boron isotope evidences from olivine-hosted melt inclusions. Geochem Geophys Geosyst 9:Q12027. https://doi:10.1029/2008GC002173

Le Voyer M, Rose-Koga EF, Shimizu N, Grove TL Schiano P (2010) Two contrasting H2O-rich components in primary melt inclusions from Mount Shasta. J. Petrol. 51:1571-1595

Leroux P, Shirey S, Hauri E, Perfit M, Bender J (2006) The effects of variable sources, processes and contaminants on the composition of northern EPR MORB $\left(8-10^{\circ} \mathrm{N}\right.$ and $\left.12-14^{\circ} \mathrm{N}\right)$ : Evidence from volatiles $\left(\mathrm{H}_{2} \mathrm{O}, \mathrm{CO}_{2}, \mathrm{~S}\right)$ and halogens (F, Cl). Earth and Planetary Science Letters 251:209-231

Médard E, Schmidt M, Schiano P, Ottolini L (2006) Melting of Amphibole-bearing Wehrlites: an Experimental Study on the Origin of Ultra-calcic Nepheline-normative Melts. Journal of Petrology 47:481-504

Métrich N, Clocchiatti R, Mosbah M, Chaussidon M (1993) The 1989-1990 activity of Etna magma mingling and ascent of H2O-Cl-S-rich basaltic magma. Evidence from melt inclusions. J. Volcanol. Geoth. Res. 59:131-144

Métrich N, Schiano P, Clocchiatti R, Maury RC (1999) Transfer of sulfur in subduction settings: An example from Batan island (Luzon volcanic arc, Philippines). Earth Planet. Sci. Lett. 167: 1-14

Métrich N, Allard P, Spilliaert N, Andronico D, Burton M (2004) 2001 flank eruption of the alkali- and volatile-rich primitive basalt responsible for Mount Etna's evolution in the last three decades. Earth Planet. Sci. Lett. 228: 1-17

Michaud F, Chabert A, Collot JY, Sallarès V, Flueh ER, Charvis P, Graindorge D, Gutscher MA, Bialas G (2005) Fields of multikilometer-scale sub-circular depressions in the Carnegie Ridge sedimentary blanket: Effect of underwater carbonate dissolution? Marine Geology 216: 205-219. doi: 10.1016/j.margeo.2005.01.003

Monzier M, Robin C, Samaniego P, Hall ML, Cotten J, Mothes P, Arnaud N (1999) Sangay volcano, Ecuador: structural development, present activity and petrology. Journal of Volcanology and Geothermal Research 90:49-79

Myers ML, Geist DJ, Rowe MC, Harpp KS, Wallace PJ, Dufek J (2014) Replenishment of volatile-rich mafic magma into a degassed chamber drives mixing and eruption of Tungurahua volcano. Bulletin of Volcanology 76:872. https://doi.org/10.1007/ s00445-014-0872-0

Nandedkar RH, Ulmer P, Müntener O (2014) Fractional crystallization of primitive, hydrous arc magmas: an experimental study at 0.7 GPa. Contrib. Mineral. Petrol. 167:1015 
O'Hara MJ (1976) Data reduction and projection schemes for complex compositions. Progress in Experimental Petrology 6:103-126

Ordóñez J (2012) Depósitos volcánicos del Pleistoceno Tardío en la cuenca de Ambato: caracterización, distribución y origen. Proyecto de Titulación para obtener el título de Ingeniero Geólogo, Quito (Ecuador), EPN.

Peccerillo A, Taylor SR (1976) Geochemistry of Eocene calc-alkaline volcanic rocks from the Kastamonu area, northern Turkey. Contributions to mineralogy and petrology 58:63-81

Pilet, S., Baker, M. B., \& Stolper, E. M. (2008). Metasomatized Lithosphere and the Origin of Alkaline Lavas. Science, 320: 916-919. https://doi.org/10.1126/science.1156563

Pratt WT, Duque P, Ponce M (2005) An autochthonous geological model for the eastern Andes of Ecuador. Tectonophysics 399:251-278. https://doi.org/10.1016/ j.tecto.2004.12.025

Proust JN, Martillo C, Michaud F, Collot JY, Dauteuil O (2016) Subduction of seafloor asperities revealed by a detailed stratigraphic analysis of the active margin shelf sediments of Central Ecuador, Mar Geol 380:345-362. https://doi:10.1016/j.margeo.2016.03.014

Prevot R, Chatelain J, Guillier B, Yepes H (1996) Mapping of the P-wave velocity structure beneath the Ecuadorian Andes: evidence for continuity of the Central Andes. Comptes Rendus Acad. Sci. Ser II-A 323:833-840

Robin C, Eissen JP, Samaniego P, Martin H, Hall ML, Cotten J (2009) Evolution of the late Pleistocene Mojanda-Fuya Fuya volcanic complex (Ecuador), by progressive adakitic involvement in mantle magma sources. Bull Volcanol 71:233-258. https://doi: 10.1007/s00445-008-0219-9

Robin C, Samaniego P, Le Pennec JL, Fornari M, Mothes P, van der Plitch J (2010) New radiometric and petrological constraints on the evolution of the Pichincha volcanic complex (Ecuador). Bull Volcanol 72:1109-1129

Rose-Koga EF, Koga KT, Hamada M, Hélouis T, Whitehouse MJ, Shimizu N (2014) Volatile (F and Cl) concentrations in Iwate olivine-hosted melt inclusions indicating low-temperature subduction. Earth, Planets and Space 66:1-12

Rose-Koga EF, Koga KT, Schiano P, Le Voyer M, Shimizu N, Whitehouse MJ, Clocchiatti R (2012) Mantle source heterogeneity for South Tyrrhenian magmas revealed by $\mathrm{Pb}$ isotopes and halogen contents of olivine-hosted melt inclusions. Chemical Geology 334:266-279

Sallares V, Charvis P (2003) Crustal thickness constraints on the geodynamic evolution of the Galapagos Volcanic Province. Earth and Planetary Science Letters 214:545-559

Samaniego P, Martin H, Robin C, Monzier M (2002) Transition from calc-alkalic to adakitic magmatism at Cayambe volcano, Ecuador: Insights into slab melts and mantle wedge interactions. Geology 30:967-970 
Samaniego P, Martin H, Monzier M, Robin C, Fornari M, Eissen JP, Cotten J (2005) Temporal Evolution of Magmatism in the Northern Volcanic Zone of the Andes: The Geology and Petrology of Cayambe Volcanic Complex (Ecuador). Journal of Petrology 46:2225-2252

Samaniego P, Eissen JP, Le Pennec JL, Robin C, Hall ML, Mothes P, Chavrit D, Cotten J (2008) Pre-eruptive physical conditions of El Reventador volcano (Ecuador) inferred from the petrology of the 2002 and 2004-05 eruptions. Journal of Volcanology and Geothermal Research 176:82-93

Samaniego P, Robin C, Chazot G, Bourdon E, Cotten J (2010) Evolving metasomatic agent in the Northern Andean subduction zone, deduced from magma composition of the long-lived Pichincha volcanic complex (Ecuador). Contributions to Mineralogy and Petrology 160:239-260

Schiano P, Eiler JM, Hutcheon ID, Stolper EM (2000) Primitive CaO-rich, silica-undersaturated melts in island arc: Evidence for the involvement of clinopyroxene-rich lithologies in the petrogenesis of arc magmas. Geochem Geophys Geosyst 1:1999GC000032

Schiano P, Clocchiatti R, Ottolini L, Sbrana A (2004) The relationship between potassic, calc-alkaline and Na-alkaline magmatism in South Italy volcanoes: A melt inclusion approach. Earth and Planetary Science Letters 220:121-137

Schiano P, Monzier M, Eissen JP, Martin H, Koga KT (2010) Simple mixing as the major control of the evolution of volcanic suites in the Ecuadorian Andes. Contributions to Mineralogy and Petrology 160:297-312

Schmidt MW, Jagoutz O (2017) The global systematics of primitive arc melts. Geochem. Geophys. Geosyst. https://doi.org/10.1002/2016gc006699

Sisson TW, Grove TL (1993) Experimental investigations of the role of $\mathrm{H}_{2} \mathrm{O}$ in calc-alkaline differentiation and subduction zone magmatism. Contributions to Mineralogy and Petrology 113:143-166

Smith DJ (2014) Clinopyroxene precursors to amphibole sponge in arc crust. Nature Communications 5:4329

Sorbadere F, Schiano P, Métrich N, Garaebiti E (2011) Insights into the origin of primitive silica-undersaturated arc magmas of Aoba volcano (Vanuatu arc). Contrib Mineral Petrol 162:995-1009.

Sorbadere F, Schiano P, Métrich N (2013a) Constraints on the Origin of Nepheline-Normative Primitive Magmas in Island Arcs Inferred from Olivine-hosted Melt Inclusion Compositions. Journal of Petrology 54:215-233

Sorbadere F, Schiano P, Métrich N, Bertagnini A (2013b) Small-scale coexistence of island-arc- and enriched-MORBtype basalts in the central Vanuatu arc. Contributions to Mineralogy and Petrology 166:1305-1321

Spandler C, Pirard C (2013) Element recycling from subducting slabs to arc crust: A review. Lithos 170-171:208-223

Spilliaert N, Métrich N, Allard P (2006) S-Cl-F degassing pattern of water-rich alkali basalt: modelling and relationship with eruption styles on Mount Etna volcano. Earth Planet Sci Lett 248:772-786 
Sun SS, McDonough WS (1989) Chemical and isotopic systematics of oceanic basalts: implications for mantle composition and processes. Geological Society, London, Special Publications 42:313-345

Straub SM, Layne GD (2003) The systematics of chlorine, fluorine, and water in Izu arc front volcanic rocks: Implications for volatile recycling in subduction zones. Geochimica et Cosmochimica Acta 67:4179-4203

Syracuse EM, van Keken PE, Abers GA (2010) The global range of subduction zone thermal models. Physics of the Earth and Planetary Interiors 183:73-90

Toplis MJ (2005) The thermodynamics of iron and magnesium partitioning between olivine and liquid: criteria for assessing and predicting equilibrium in natural and experimental systems. Contributions to Mineralogy and Petrology 149:22-39

Vaggelli G, De Vivo B, Triglla R (1993) Silicate-melt inclusions in recent Vesuvius lavas (1631-1944): II. Analytical chemistry. J Volcanol Geotherm Res 58:367-376

van den Bleeken G, Koga KT (2015) Experimentally determined distribution of fluorine and chlorine upon hydrous slab melting, and implications for $\mathrm{F}-\mathrm{Cl}$ cycling through subduction zones. Geochimica et Cosmochimica Acta 171:353373

Vigouroux N, Wallace PJ, Kent AJR (2008) Volatiles in High-K Magmas from the Western Trans-Mexican Volcanic Belt: Evidence for Fluid Fluxing and Extreme Enrichment of the Mantle Wedge by Subduction Processes. Journal of Petrology 49:1589-1618

Wallace P, Carmichael ISE (1992) Sulfur in basaltic magmas. Geochimica et Cosmochimica Acta 56:1863-1874.

Walter MJ (1998) Melting of garnet peridotite and the origin of komatiite and depleted lithosphere. Journal of Petrology 39:29-60

Wasylenki LE, Baker MB, Kent AJR, Stolper EM (2003) Near-solidus Melting of the Shallow Upper Mantle: Partial Melting Experiments on Depleted Peridotite. Journal of Petrology, 44: 1163-1191. https://doi.org/10.1093/petrology/44.7.1163

Wallowski KJ, Wallace PJ, Hauri EH, Wada I, Clynne MA (2015) Slab melting beneath the Cascade Arc driven by dehydration of altered oceanic peridotite. Nature Geoscience 8:404-409

Yepes H, Audin L, Alvarado A, Beauval C, Aguilar J, Font Y, Cotton F (2016) A new view for the geodynamics of Ecuador: implication in seismogenic source definition and seismic hazard assessment. Tectonics 35:1249-1279. https://doi:10.1002/2015TC003941

\section{Figure captions}


Fig. 1 a Geodynamical setting of Ecuadorian arc. b Schematic map of the main geological zones in Ecuador [modified from Jaillard et al. (2008)]. Analyses of melt inclusions were performed in rock samples from Sangay and Puñalica volcanoes (in red). Puñalica volcano is a small, young edifice associated with the older Carihuairazo volcano . Pichincha Volcanic Complex (Pichincha) and Pan de Azúcar volcanoes, which are mentioned in the text, are in cyan. White dashed line is the surface projection of the Grijalva fracture zone (GFZ) that affects subduction and separates old oceanic lithosphere to the south from young oceanic lithosphere to the north. This projection is based on the recent seismological work of Yepes et al. (2016) studying the flexure of the subducted slab along the GFZ

Fig. 2 a $\mathrm{K}_{2} \mathrm{O}$ vs. $\mathrm{SiO}_{2}$ classification diagram (Peccerillo and Taylor 1976) of melt inclusions (homogenizationcorrected compositions; colored diamonds and triangles) and whole-rocks (shaded areas and star symbols colored to the same as their corresponding MI) of Sangay and Puñalica volcanoes. 50 melt inclusion compositions are plotted; 7 belonging to SAN20B sample from Sangay volcano and the others belonging to Punalica samples. Groups 1, 2 and 3 in the legend box correspond to the groups defined for Puñalica MI. See text for more details. b Molar $100 *(\mathrm{MgO} /$ $(\mathrm{FeOt}+\mathrm{MgO}) v s . \mathrm{SiO}_{2}$ wt.\% for melt inclusions and whole-rock lavas from Sangay and Puñalica volcanoes

Fig. 3 Harker diagram showing the composition of $\mathrm{MgO}, \mathrm{FeO}, \mathrm{Al}_{2} \mathrm{O}_{3}$ and $\mathrm{CaO}$ vs. $\mathrm{SiO}_{2}$ for melt inclusions ( homogenization-corrected compositions) and whole-rock samples (shaded areas) of Sangay and Puñalica volcanoes. The black arrows correspond to olivine fractionation lines calculated using R-MELTS program (Gualda et al. 2015), starting from one of the most primitive melt inclusions of each volcano, using a pressure of $4 \mathrm{kbar}$ and an estimated water content of 2 wt. \%. For description of symbols see Fig. 2

Fig. 4 Frequency histogram of the forsterite content of the olivine phenocrysts (a) and of melt inclusions (b) from Puñalica and Sangay volcanoes. Diagram (a) shows data from this study and that of Monzier et al. (1999). Forsterite contents for melt inclusions are plotted using homogenization-corrected values and $\mathrm{Fe}^{2+} / \sum \mathrm{Fe}$ obtained using sulfur speciation. We did not differentiate the Puñalica groups

Fig. 5 Trace element compositions of Puñalica (a-c) and Sangay (e) melt inclusions and whole-rock lavas [shaded areas, Hidalgo et al. (2012) and Ancellin et al. (2017)] normalized to Primitive Mantle composition (Sun and McDonough 
1989). d REE spider diagram for Puñalica MI. N-MORB (dashed gray line) from Sun and McDonough (1989) and EMORB (dashed black line) from Hofmann (1988)

Fig. 6 Projection from olivine $\left(\mathrm{M}_{2} \mathrm{~S}\right)$ onto the Ne-Di-Qz $\left(\mathrm{CMS}_{2}-\mathrm{S}-\mathrm{CA}\right)$ plane for whole-rock lavas and melt inclusions from Puñalica and Sangay. Schema using O'Hara (1976) CMAS component calculation. $\mathrm{C}=\mathrm{CaO}-10 / 3 \mathrm{P}_{2} \mathrm{O}_{5}+{ }_{2} \mathrm{Na}_{2} \mathrm{O}$ $+2 \mathrm{~K}_{2} \mathrm{O}, \mathrm{M}=\mathrm{MgO}+\mathrm{FeO}+\mathrm{MnO}-\mathrm{TiO}_{2}, \mathrm{~A}=\mathrm{Al}_{2} \mathrm{O}_{3}+\mathrm{Fe}_{2} \mathrm{O}_{3}+\mathrm{TiO}_{2}+\mathrm{Na}_{2} \mathrm{O}+\mathrm{K}_{2} \mathrm{O}, \mathrm{S}=\mathrm{SiO}_{2}-2 \mathrm{Na}_{2} \mathrm{O}-2 \mathrm{~K}_{2} \mathrm{O}$. Also shown in the diagram are the fields compiled by Sorbadere et al. (2013a) of experimentally determined melts of anhydrous (Hirose and Kushiro 1993; Baker and Stolper 1994; Kushiro 1996; Falloon et al. 2001; Wasylenki et al. 2003; Laporte et al. 2004) and hydrous peridotites between 0.5 and $3.5 \mathrm{GPa}$ (continuous lines are isobars with pressure given in GPa; Hirose and Kawamoto 1995; Gaetani and Grove 1998), amphibole-free (Kogiso and Hirschmann, 2001) and amphibole-bearing clinopyroxenites between 0.5 and 1.5 GPa (Médard et al. 2006; Pilet et al. 2008)

Fig. $7 \mathrm{La} / \mathrm{Yb}$ vs. wt. $\% \mathrm{Al}_{2} \mathrm{O}_{3}$ of melt inclusions and whole-rocks. $\mathrm{La} / \mathrm{Yb}$ ratio is explained by 1 to $8 \%$ of garnet in the mantle residue following the model proposed for Puñalica MIs (see text)

Fig. 8 Plot of $(\mathrm{La} / \mathrm{Yb})_{\mathrm{N}}$ normalized to primitive mantle (Sun and McDonough 1989) versus a $\mathrm{Sr} / \mathrm{Th}$ and $\mathbf{b} \mathrm{Ba} / \mathrm{Th}$. Whole-rock data variation for Pichincha Volcanic Complex field is taken from Samaniego et al. (2010). Purple field corresponds to the older Rucu Pichincha magmatic suite whereas yellow field corresponds to the field of the younger Guagua Pichincha suite. MORB composition represented by the small black rectangle is from Leroux et al. (2006). The primitive arc magma composition (dotted field) is taken from Elliott (2003). Symbols are those of Fig. 2

Fig. 9 Modeled composition (colored dashed lines) compared to natural melt inclusion (colored solid lines) from (a) Puñalica and (b) Sangay volcanoes. (c) Modeled composition for SAN20B whole-rock sample from Sangay volcano. Gray dot-dash lines are compositions of the non-metasomatized source lithologies: a depleted mantle (Workman and Hart, 2005) for Puñalica and SAN20B, and a clinopyroxenite (Smith 2014) for Sangay. The proportion of slab component compared to peridotite/clinopyroxenite in the mixing process is 10:90 for Puñalica MI, 12:88 for Sangay MI and 15:85 for SAN20B. The amount of sedimentary-origin melt in the slab component is $20 \%$ (only for Puñalica). 
825 Fig. $10 \mathrm{~F} v s . \mathrm{Cl}$ for Sangay and Puñalica melt inclusions. Our data is compared to other melt inclusion compositions 826 compiled by Rose-Koga et al. (2014). Melt inclusion compositions from Payenia backarc are from Brandt et al. (2017b). 


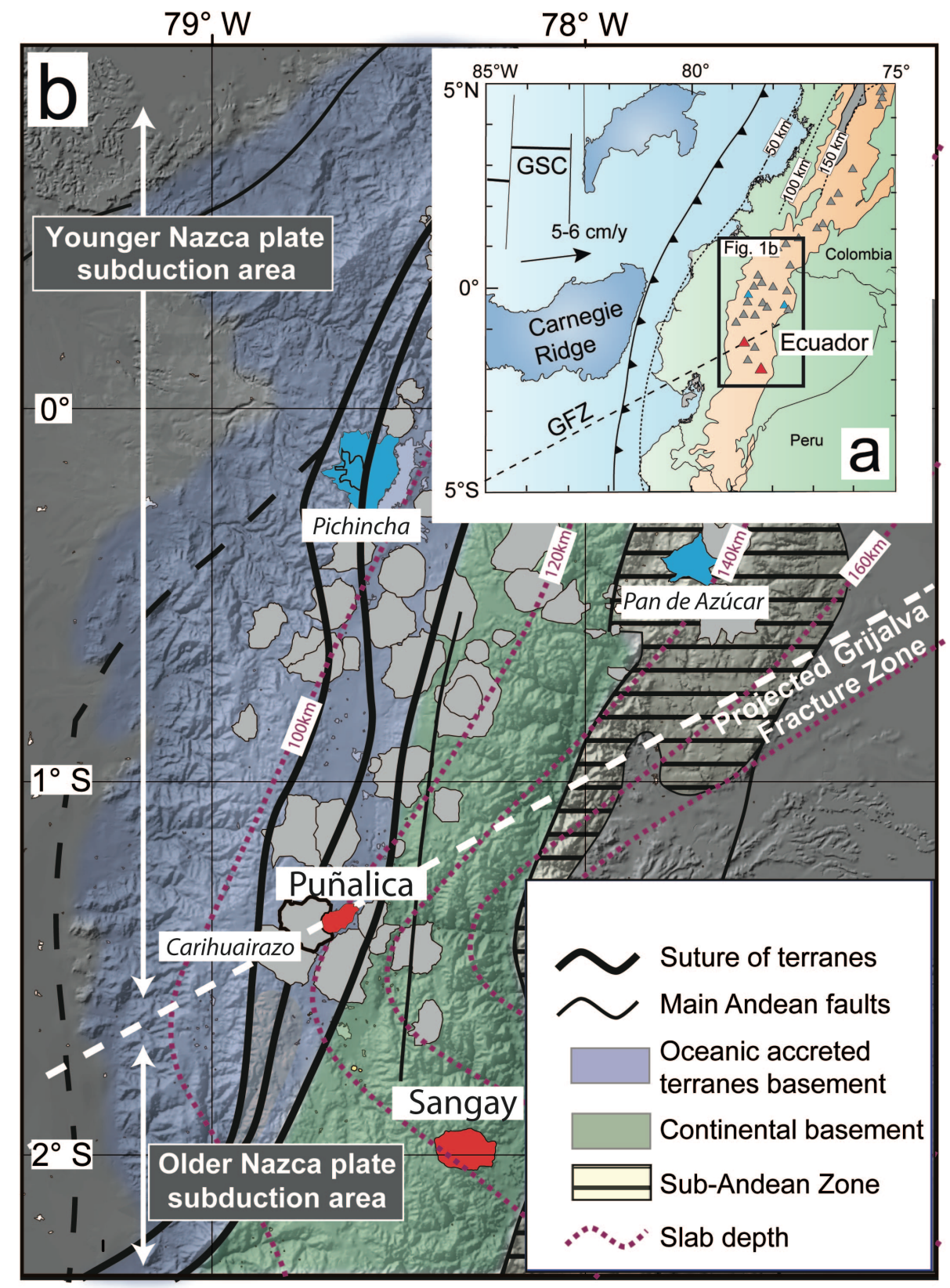




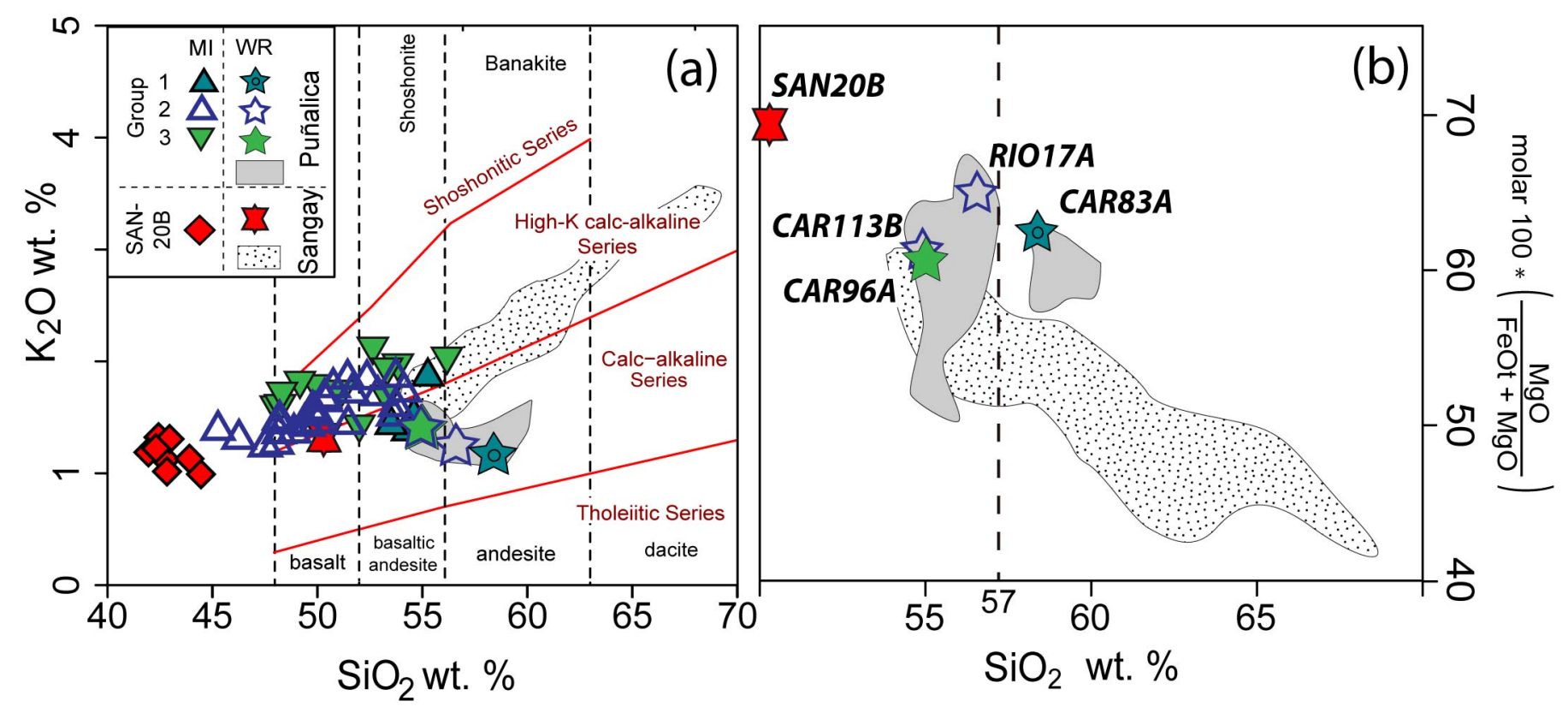



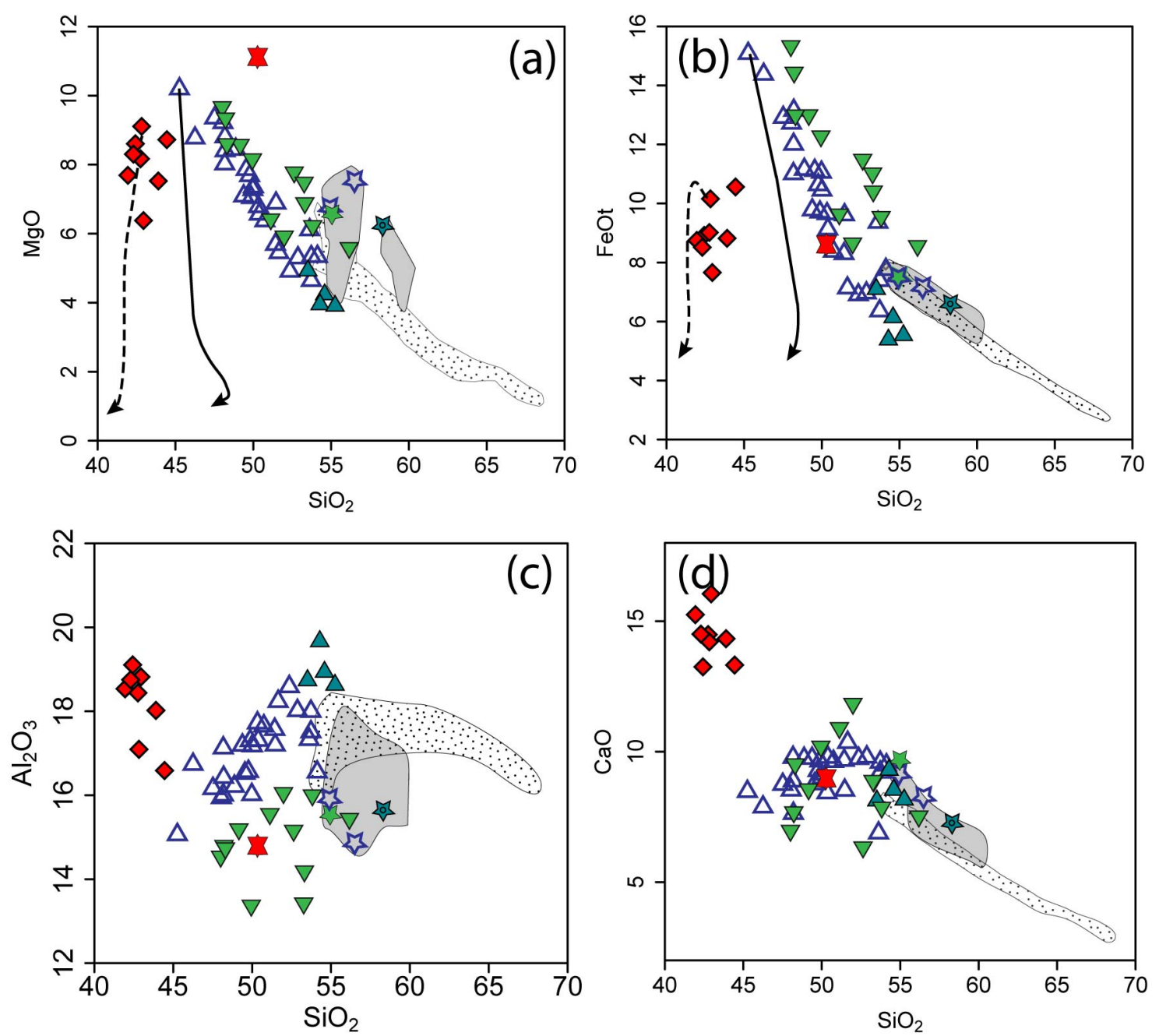

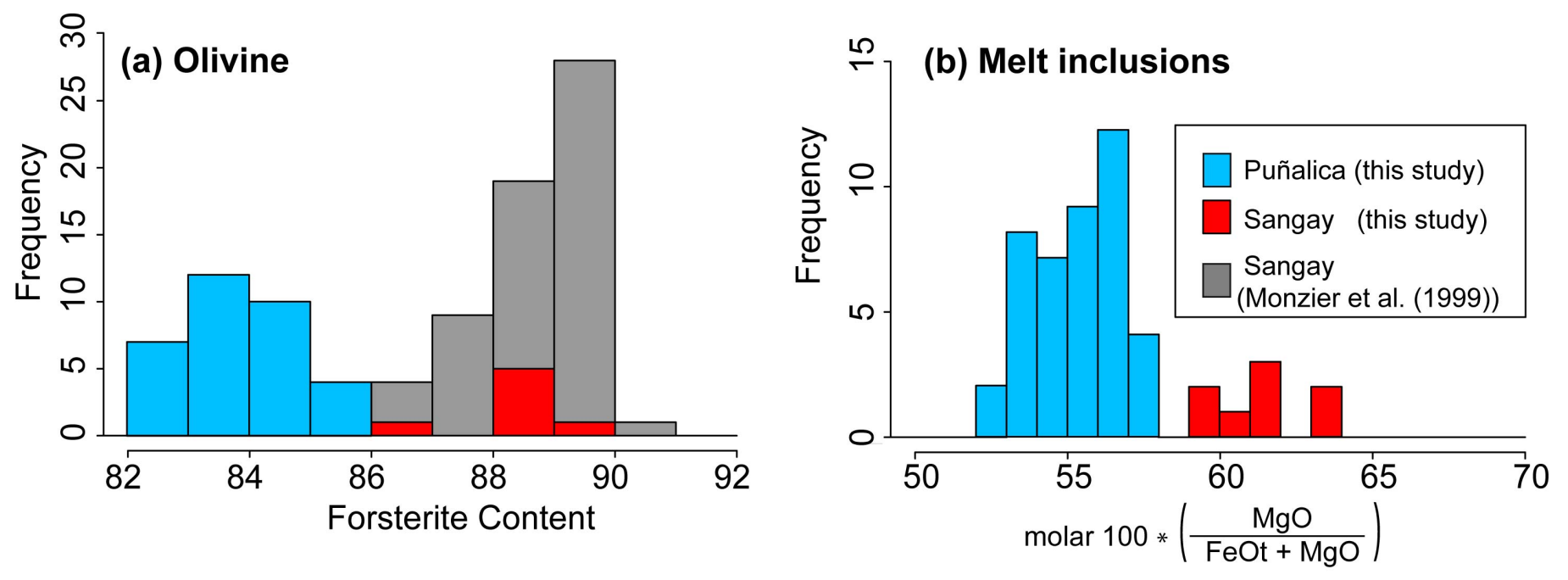

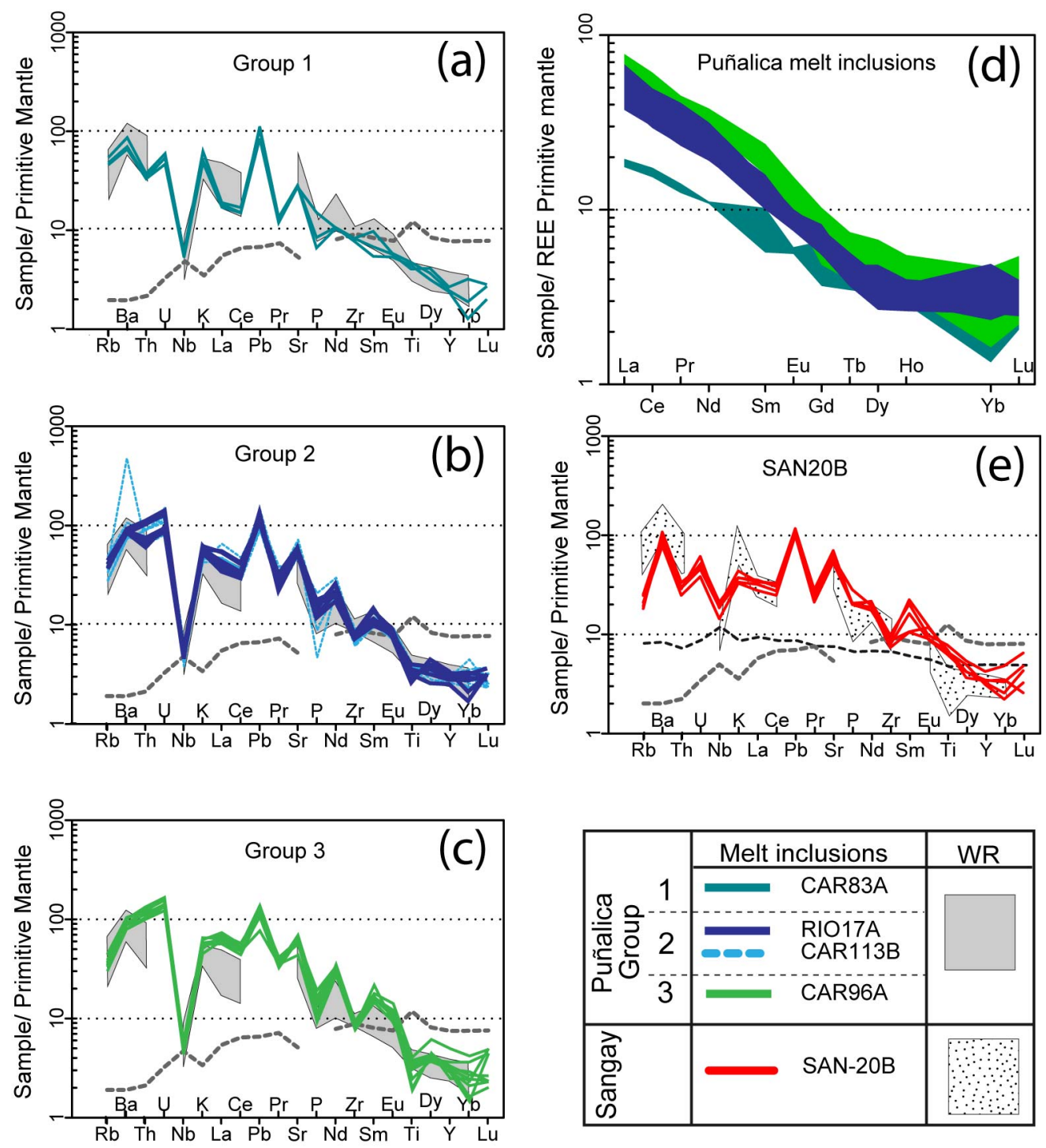

\begin{tabular}{|c|c|c|c|}
\hline \multirow{4}{*}{ 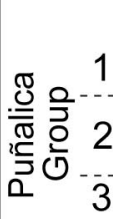 } & Melt i & clusions & WR \\
\hline & 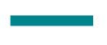 & CAR83A & \\
\hline & -0 & $\begin{array}{l}\text { RIO17A } \\
\text { CAR113B }\end{array}$ & \\
\hline & 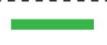 & CAR96A & \\
\hline 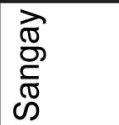 & & SAN-20B & \\
\hline
\end{tabular}




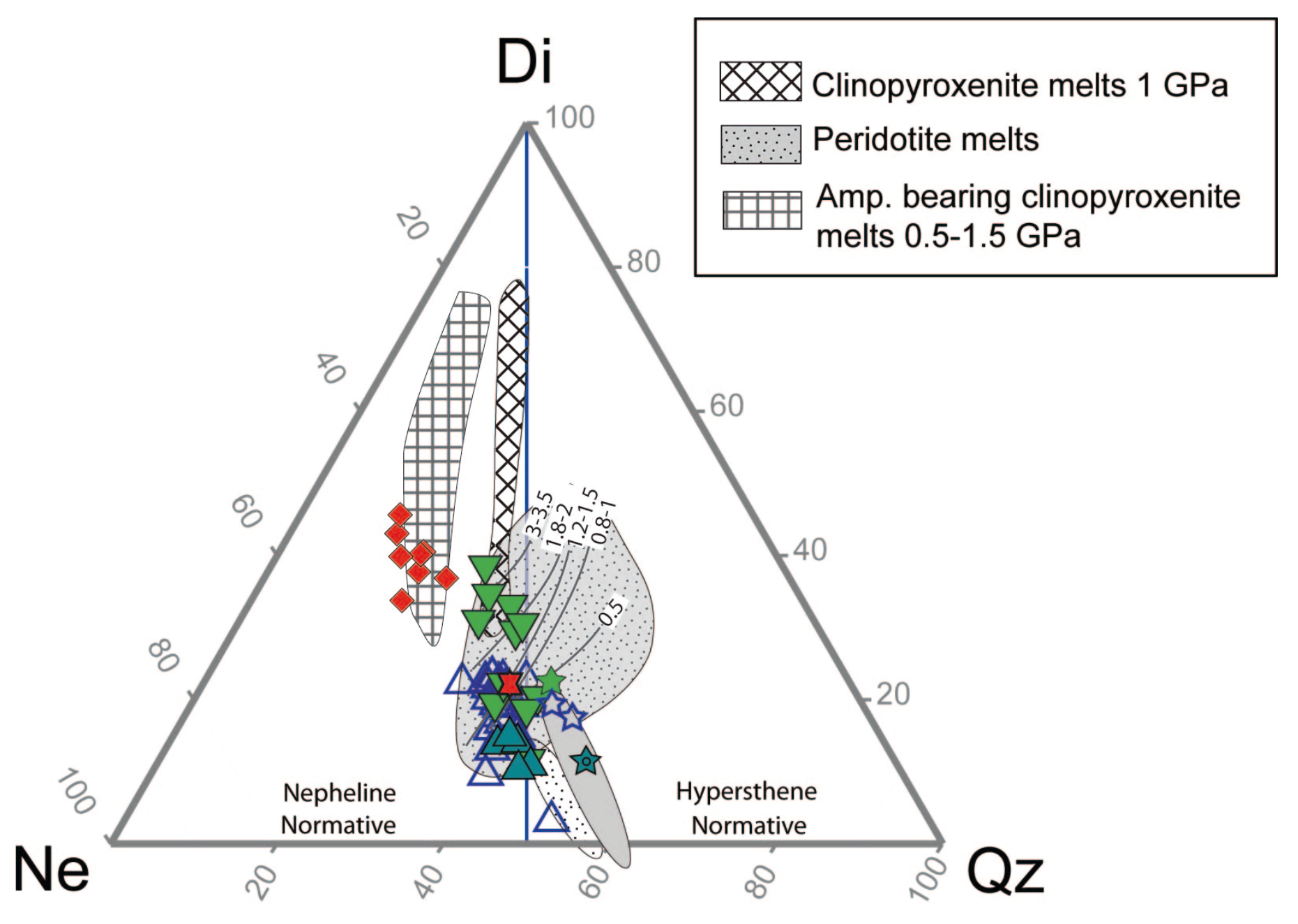




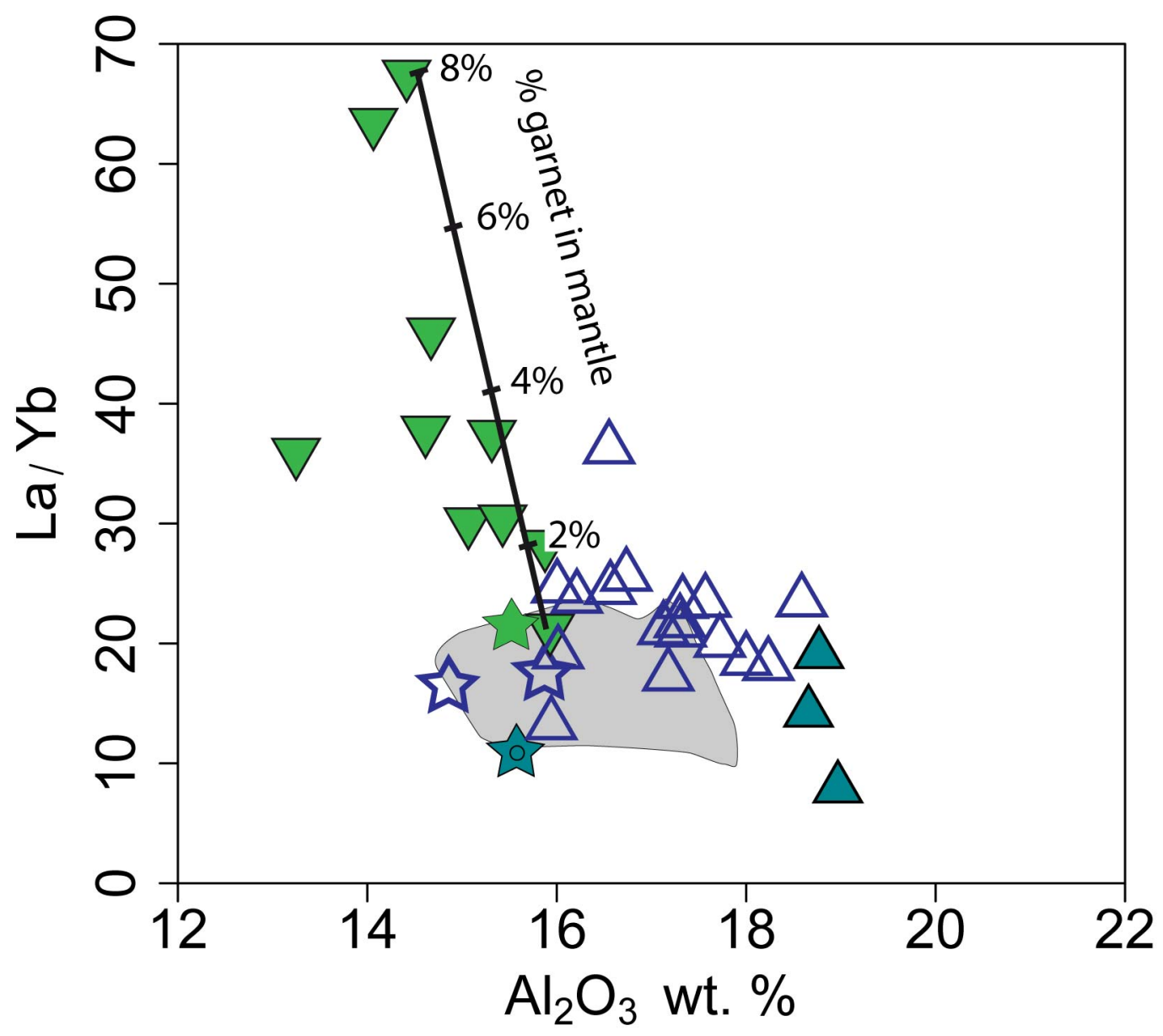




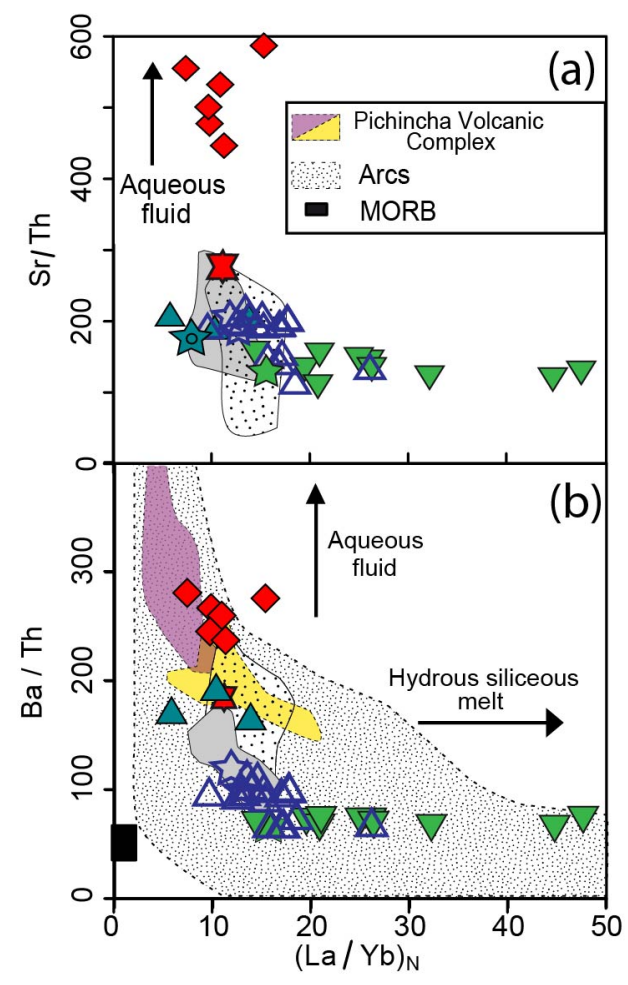



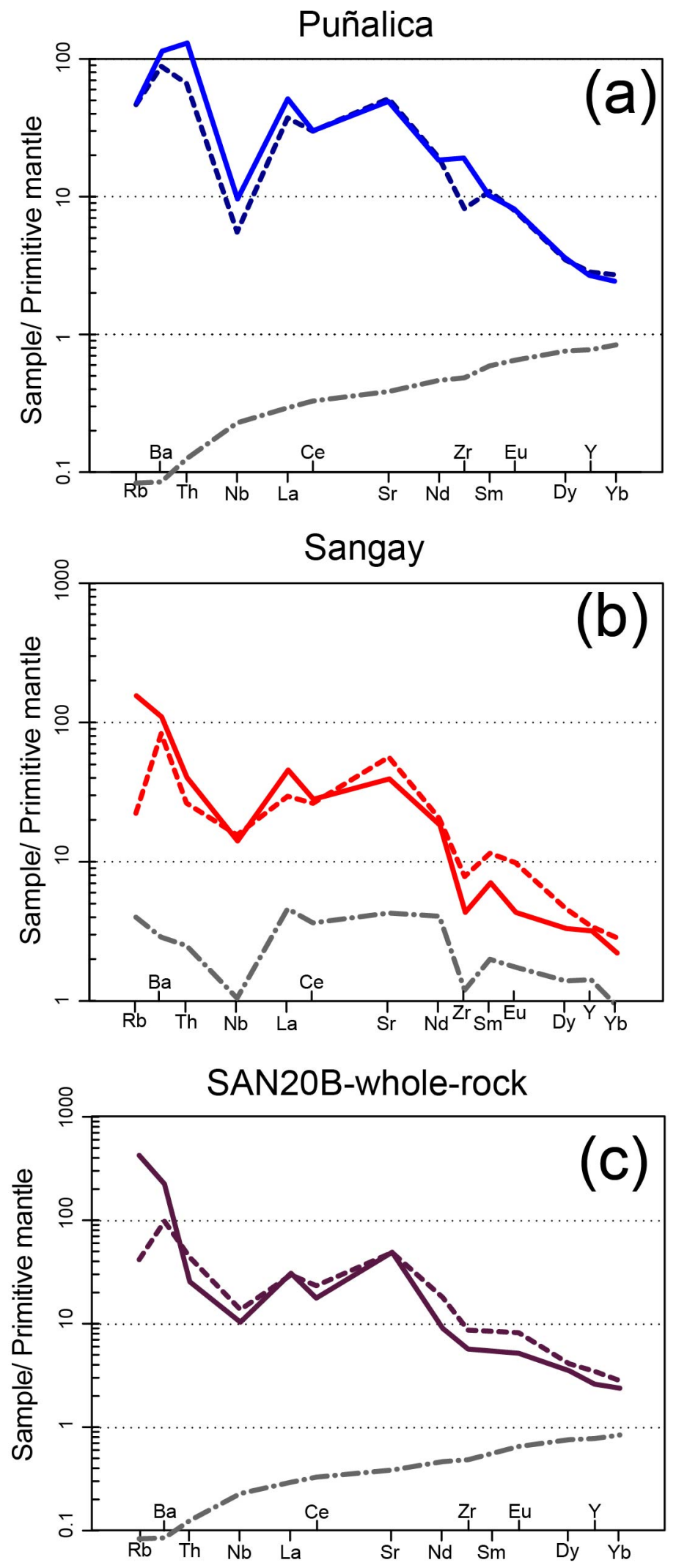
Table 1 Major, trace elements and volatile concentrations of olivine-hosted melt inclusions from Puñalica and Sangay lavas. Total given are the values. Major elements are the corrected values after wall olivine crystallization.

\begin{tabular}{|c|c|c|c|c|c|c|c|c|c|c|c|c|c|c|}
\hline & \multicolumn{8}{|c|}{ Sangay volcano } & \multicolumn{6}{|c|}{ Puñalica volcano } \\
\hline & \multicolumn{8}{|c|}{ SAN20B } & & & \multicolumn{4}{|c|}{ CAR96A } \\
\hline & $\overline{\mathrm{A}}$ & $\bar{B}$ & $\overline{\mathrm{C}}$ & $\overline{\mathrm{D}}$ & $\overline{\mathrm{E}}$ & $\overline{E \text { E1 }}$ & $\overline{\mathrm{F}}$ & $\overline{\bar{G}}$ & $\mathrm{AA}$ & $\mathrm{AB}$ & $\mathrm{AC}$ & $\mathrm{AE}$ & $\mathrm{AF}$ & $\overline{A G}$ \\
\hline $\mathrm{SiO} 2$ & 42.43 & 42.76 & 44.45 & 42.83 & 41.95 & 42.95 & 43.9 & 42.3 & 56.16 & 48.01 & 53.82 & 48.22 & 49.95 & 51.99 \\
\hline TiO2 & 1.53 & 1.7 & 1.48 & 1.36 & 18 & 1.65 & 1.45 & 1.41 & 0.41 & $\begin{array}{l}40.01 \\
0.75\end{array}$ & 0.53 & 0.67 & 0.68 & 0.88 \\
\hline $\mathrm{A} 12 \mathrm{O} 3$ & 19.11 & 18.44 & 16.59 & 17.09 & 18.53 & 18.82 & 18.02 & 18.75 & 15.32 & 14.41 & 15.88 & 14.67 & 13.25 & $\begin{array}{l}0.00 \\
15.93\end{array}$ \\
\hline FeOt & 8.92 & $\begin{array}{l}10.44 \\
9.02\end{array}$ & 10.56 & 10.16 & 8.75 & $\begin{array}{l}10.06 \\
7.66\end{array}$ & 8.82 & 8.51 & 8.39 & 15.16 & 9.37 & 14.26 & 12.1 & 8.48 \\
\hline $\mathrm{MnO}$ & 0.17 & 0.14 & 0.1 & 0.06 & 0.22 & 0.12 & 0.22 & 0.15 & 0.08 & 0.03 & 0.22 & 0.13 & 0.16 & 0.11 \\
\hline $\mathrm{MgO}$ & 8.6 & 8.17 & 8.72 & 9.11 & 7.69 & 6.38 & 7.53 & 8.3 & 5.44 & 9.52 & 6.07 & 9.19 & 8.01 & 5.77 \\
\hline $\mathrm{CaO}$ & 13.25 & 14.49 & 13.32 & 14.21 & 15.25 & 16.05 & 14.33 & 14.5 & 7.4 & 6.77 & 7.66 & 7.48 & 10 & 11.64 \\
\hline $\mathrm{Na} 2 \mathrm{O}$ & 4.24 & 3.73 & 3.35 & 3.55 & 4.25 & 4.62 & 4.17 & 4.28 & 4.48 & 3.48 & 4.17 & 3.5 & 3.83 & 3.6 \\
\hline $\mathrm{K} 2 \mathrm{O}$ & 1.32 & 1.12 & 0.99 & 1.02 & 1.19 & 1.31 & 1.13 & 1.22 & 1.97 & 1.53 & 1.91 & 1.54 & 1.72 & 1.36 \\
\hline P2O5 & 0.44 & 0.45 & 0.44 & 0.62 & 0.37 & 0.44 & 0.44 & 0.57 & 0.35 & 0.34 & 0.36 & 0.33 & 0.3 & 0.25 \\
\hline Total & 94.56 & 94.75 & 93.82 & 95.3 & 96.39 & 98.36 & 96.41 & 92.92 & 99.27 & 99.15 & 99.68 & 98.35 & 97.6 & 99.3 \\
\hline $\mathrm{H} 2 \mathrm{O}$ & & & 3.17 & 2.6 & & & & & 0.09 & 0.1 & 0.09 & 0.1 & 0.07 & 0.07 \\
\hline $\mathrm{CO} 2(\mathrm{ppm})$ & & & 2776 & 6088 & & & & & 252 & 625 & 201 & 658 & 826 & 123 \\
\hline $\mathrm{F}(\mathrm{ppm})$ & $913^{\mathrm{b}}$ & $843^{b}$ & 720 & 627 & $963^{b}$ & $1183^{b}$ & $791^{\mathrm{b}}$ & $873^{b}$ & 1626 & 1448 & 1492 & 1222 & 1388 & 1061 \\
\hline $\mathrm{Cl}(\mathrm{ppm})$ & $2257^{b}$ & $2052^{b}$ & 1636 & 1776 & $2193^{b}$ & $2227^{b}$ & $1941^{b}$ & $2213^{b}$ & 5947 & 5813 & 5305 & 4958 & 5985 & 3928 \\
\hline $\mathrm{S}(\mathrm{ppm})$ & $5417^{\mathrm{b}}$ & $3857^{\mathrm{b}}$ & 4029 & 3836 & $4519^{b}$ & $4480^{b}$ & $4552^{b}$ & $5473^{b}$ & 2467 & 3140 & 2829 & 3109 & 4805 & 2152 \\
\hline $\mathrm{Sc}$ & 25.5 & 43.2 & 28.2 & 27.8 & 42.3 & & 38.5 & & 14.5 & 17.1 & 16.2 & 15 & 35.7 & 46.1 \\
\hline $\mathrm{V}$ & 393.3 & 407.2 & 317.7 & 355.8 & 414.1 & & 382.3 & & 189.2 & 375.1 & 219.4 & 237.4 & 306.9 & 204.9 \\
\hline $\mathrm{Rb}$ & 11.6 & 16.1 & 13.4 & 12.3 & 17.3 & & 15.7 & & 28.4 & 21.7 & 28.1 & 21.1 & 22.1 & 19.1 \\
\hline $\mathrm{Sr}$ & 1356.4 & 1360.1 & 1123.4 & 1252.2 & 1420.3 & & 1485 & & 1459 & 1280.6 & 1332.7 & 1188.1 & 1351.4 & 1279.8 \\
\hline $\mathrm{Nb}$ & $\begin{array}{l}1350.4 \\
14.2\end{array}$ & 13.2 & $10.3^{4}$ & $13.4^{2}$ & $\begin{array}{l}1420.5^{3} \\
15.5\end{array}$ & & $\begin{array}{l}1403 \\
15.1\end{array}$ & & $\begin{array}{c}1439 \\
3.9\end{array}$ & 3.3 & $\begin{array}{c}1532.1 \\
4.2\end{array}$ & $\begin{array}{l}1100.1 \\
3.4\end{array}$ & $\begin{array}{l}1531.4 \\
3.5\end{array}$ & 3.1 \\
\hline $\mathrm{Ta}$ & 1.1 & 1.4 & 0.4 & 0.8 & 0.8 & & 0.8 & & $<0.192$ & $<0.17$ & 0.3 & 0.2 & 0.3 & 0.2 \\
\hline $\mathrm{Ba}$ & 758.6 & 688.6 & 549 & 613.8 & 755.4 & & 698.4 & & 720.9 & 728.8 & 712.7 & 639.6 & 651.8 & 554.2 \\
\hline $\mathrm{La}$ & 23.5 & 24.4 & 19.1 & 22 & 26.4 & & 23.3 & & 44 & 47.8 & 48.9 & 46.7 & 40.1 & 41.8 \\
\hline $\mathrm{Ce}$ & 58.2 & 54.1 & 44.1 & 48.8 & 61.3 & & 57.5 & & 85.9 & 102.1 & 97.2 & 93.1 & 85 & 86.7 \\
\hline $\mathrm{Pb}$ & 8.2 & 8.3 & 7.1 & 7.8 & & & 8.3 & & 8.5 & $8 . \dot{4}^{1}$ & 9.8 & 8.1 & 7.5 & 9.1 \\
\hline $\mathrm{Nd}$ & 29.3 & 28.8 & 25.6 & 26.6 & 35.9 & & 23.7 & & 41.4 & 41.8 & 46.3 & 43.3 & 38.2 & 47.5 \\
\hline $\mathrm{Sm}$ & 4.7 & 9 & 4.7 & 7.2 & 9.7 & & 10 & & 7.3 & 9.7 & 7 & 7.2 & 7.1 & 8 \\
\hline $\mathrm{Zr}$ & 96.3 & 109.9 & 82.3 & 88.3 & 112.5 & & 96.8 & & 97.4 & 93.9 & 97.8 & 89.8 & 89.6 & 105.6 \\
\hline $\mathrm{Eu}$ & 2 & 1.7 & 1.5 & 1.5 & 1.9 & & 2 & & 2 & 1.5 & 2 & $2^{\circ}$ & 1.8 & $2.4^{\circ}$ \\
\hline $\mathrm{Gd}$ & 3.7 & 3.6 & 4.3 & 5.6 & 4.8 & & 2.9 & & 4.1 & 3 & 4.9 & 4.6 & 2.6 & 5.4 \\
\hline Dy & 2.7 & 4 & 3.1 & 3.1 & 5.2 & & 3.6 & & 3.3 & 3.1 & 2.9 & 2.9 & 3.1 & 4.5 \\
\hline $\mathrm{Yb}$ & 1.7 & 2.4 & 1.3 & 1.6 & 1.7 & & 1.1 & & 1.2 & 0.7 & 1.8 & $i$ & 1.2 & 2.1 \\
\hline $\mathrm{Th}$ & 2.8 & 2.5 & 2.1 & 2.5 & 3.2 & & 2.5 & & 10.5 & 10.4 & 10.4 & 10.2 & 9.5 & 8.5 \\
\hline $\mathrm{U}$ & $i$ & 1.3 & 0.8 & $i$ & 0.8 & & 0.3 & & 3.3 & 3.5 & 3.3 & 3.4 & 2.9 & 2.6 \\
\hline $\mathrm{Pr}$ & 6.4 & 69 & $\begin{array}{l}0.0 \\
5.9\end{array}$ & 6.5 & 7.5 & & 7.8 & & 9.8 & 11.1 & 109 & 10.7 & 9 & 10.8 \\
\hline $\mathrm{Y}$ & 15.4 & 19.2 & 14.8 & $\begin{array}{l}0.3 \\
15.7\end{array}$ & 20 & & 14.2 & & $\begin{array}{l}9.0 \\
11.3\end{array}$ & 12.9 & 16.6 & 13.4 & 14.6 & 22.6 \\
\hline $\mathrm{Lu}$ & $<0.19$ & $<0.48$ & 0.3 & 0.4 & $<0.32$ & & $<0.24$ & & $<0.174$ & 0.3 & 0.3 & 0.2 & 0.4 & 0.4 \\
\hline Fo olivine & 0.89 & 0.88 & 0.87 & 0.88 & 0.88 & 0.88 & 0.88 & 0.89 & & 0.82 & 0.83 & 0.83 & 0.83 & 0.83 \\
\hline $\mathrm{Ne}$ & 19.40 & 17.06 & 14.90 & 16.24 & 19.44 & 21.14 & $\begin{array}{l}0.00 \\
19.07\end{array}$ & 19.58 & & $\begin{array}{l}0.02 \\
4.10\end{array}$ & & $\begin{array}{l}0.05 \\
4.80\end{array}$ & $\begin{array}{l}0.03 \\
7.90\end{array}$ & 2.80 \\
\hline$H y$ & & & & & & & & & 8.65 & & 1.27 & & & \\
\hline
\end{tabular}

* Samples with $>10 \%$ of olivine crystallization correction. ${ }^{5} \mathrm{~F}, \mathrm{Cl}$ and $\mathrm{F}$ values from EMP, the other values for these volatiles are from SIMS. Ne normative composition 
Table 1 continued

Puñalica volcano

\begin{tabular}{|c|c|c|c|c|c|c|c|c|c|c|c|c|c|c|c|}
\hline \multicolumn{11}{|c|}{ CAR96A } & \multicolumn{5}{|c|}{ CAR113B } \\
\hline AG1 & $\mathrm{AH}$ & & AH1 & $\mathrm{AI}$ & $\overline{\mathrm{AJ}}$ & $\mathrm{AK}$ & $\overline{\mathrm{H}}$ & H1 & $\overline{\mathrm{I}}$ & $\overline{\mathrm{J}}$ & $\overline{\mathrm{J} 1}$ & $\mathrm{~K}^{*}$ & $\mathrm{~K} 2$ & $\overline{\mathrm{L}}$ & $\overline{\mathrm{M}}$ \\
\hline 52.63 & 53.31 & $\mathrm{SiO} 2$ & 53.27 & 49.16 & 51.12 & 48.3 & 48.05 & 47.52 & 52.35 & 48.17 & 49.88 & 53.62 & 46.26 & 49.77 & 50.01 \\
\hline 0.63 & 0.43 & $\mathrm{TiO} 2$ & 0.46 & 0.79 & 0.82 & 0.72 & 0.74 & 0.65 & 0.78 & 0.79 & 0.85 & 0.86 & 0.79 & 0.74 & 0.75 \\
\hline 15.03 & 14.06 & Al2O3 & 13.3 & 15.07 & 15.43 & 14.61 & 15.94 & 16.16 & 18.59 & 17.13 & 17.3 & 17.33 & 16.74 & 16.57 & 17.18 \\
\hline 11.31 & 10.23 & $\mathrm{FeOt}$ & 10.85 & 12.82 & 9.46 & 12.81 & 12.72 & 12.92 & 6.91 & 11.01 & 9.71 & 9.36 & 14.38 & 10.63 & 10.45 \\
\hline 0.16 & 0.13 & $\mathrm{MnO}$ & 0.06 & 0.18 & 0.18 & 0.13 & 0.04 & 0.16 & 0.11 & 0.17 & 0.11 & 0.21 & 0.08 & 0.07 & 0.22 \\
\hline 7.63 & 6.74 & $\mathrm{MgO}$ & 7.33 & 8.43 & 6.27 & 8.45 & 9.22 & 9.35 & 4.91 & 8.02 & 7.04 & 6.11 & 8.77 & 7.68 & 7.36 \\
\hline 6.14 & 8.67 & $\mathrm{CaO}$ & 8.68 & 8.36 & 10.71 & 9.32 & 8.53 & 8.74 & 9.74 & 9.78 & 9.65 & 6.88 & 7.88 & 9.27 & 9 \\
\hline 3.95 & 4.14 & $\mathrm{Na} 2 \mathrm{O}$ & 3.98 & 3.23 & 4.14 & 3.69 & 3.2 & 3.05 & 4.47 & 3.23 & 3.63 & 3.75 & 3.36 & 3.6 & 3.27 \\
\hline 2.06 & 1.87 & $\mathrm{~K} 2 \mathrm{O}$ & 1.63 & 1.75 & 1.67 & 1.65 & 1.26 & 1.24 & 1.84 & 1.36 & 1.55 & 1.51 & 1.31 & 1.57 & 1.45 \\
\hline 0.47 & 0.42 & P2O5 & 0.45 & 0.21 & 0.2 & 0.3 & 0.29 & 0.21 & 0.31 & 0.34 & 0.28 & 0.37 & 0.44 & 0.1 & 0.31 \\
\hline \multirow[t]{3}{*}{99.52} & 99.46 & Total & 98.57 & 100.68 & 97.48 & 97.92 & 96.62 & 96.55 & 98.18 & 95.04 & 95.23 & 98.99 & 101.04 & 97.62 & 97.89 \\
\hline & 0.07 & $\mathrm{H} 2 \mathrm{O}$ & & & 0.07 & 0.06 & 1.63 & & 0.33 & 2.35 & 3.07 & & & & 1.98 \\
\hline & 308 & $\mathrm{CO} 2(\mathrm{ppm})$ & & & 296 & 512 & 2053 & & 262 & 802 & 376 & & & & 645 \\
\hline $2187^{b}$ & 1194 & $\mathrm{~F}(\mathrm{ppm})$ & $1412^{b}$ & 596 & 950 & 922 & 503 & & 624 & 518 & 699 & & $655^{b}$ & 673 & 483 \\
\hline $5418^{\mathrm{b}}$ & 5629 & $\mathrm{Cl}$ (ppm) & $5252^{\mathrm{b}}$ & 3460 & 5458 & 4927 & 4021 & & 5187 & 4598 & 4037 & & $4137^{b}$ & 5861 & 4318 \\
\hline \multirow{23}{*}{$2590^{b}$} & 4434 & $\mathrm{~S}(\mathrm{ppm})$ & $4362^{b}$ & 1151 & 4331 & 4751 & 3818 & & 1959 & 4701 & 6020 & & $1635^{\mathrm{b}}$ & 4396 & 4271 \\
\hline & 34.7 & $\mathrm{Sc}$ & & 29.6 & 31.9 & 27 & 21.4 & & 20.4 & 23.1 & 19.9 & 16 & 22.1 & 21.6 & 20.5 \\
\hline & 173.1 & $\mathrm{~V}$ & & 274.5 & 190.5 & 240.9 & 216.2 & & 183.2 & 216.4 & 214.2 & 166.3 & 251.8 & 199.8 & 206.6 \\
\hline & 24.6 & $\mathrm{Rb}$ & & 23.6 & 23.5 & 22.9 & 21 & & 30.8 & 22.6 & 17.8 & 25.3 & 22.9 & 24.6 & 21.3 \\
\hline & 1290.5 & $\mathrm{Sr}$ & & 919.1 & 1298.8 & 1240.6 & 1129.3 & & 1487.1 & 1228.6 & 1118 & 1021.5 & 935.8 & 1257.7 & 1110.7 \\
\hline & 3.6 & $\mathrm{Nb}$ & & 3.4 & 3.4 & 3.3 & 3.6 & & 4.6 & 3.4 & 2.7 & 3 & 3.6 & 3.8 & 3.2 \\
\hline & 0.2 & Ta & & 0.2 & 0.2 & 0.2 & $<0.20$ & & 0.2 & 0.2 & 0.1 & 0.1 & $<0.22$ & $<0.120$ & 0.2 \\
\hline & 700.5 & $\mathrm{Ba}$ & & 558 & 611.1 & 633.2 & 571.9 & & 732.4 & 583.9 & 507 & 3275.6 & 620.8 & 626.6 & 527.7 \\
\hline & 50.5 & $\mathrm{La}$ & & 41.8 & 38.9 & 44.7 & 28.9 & & 37.4 & 31 & 31.5 & 26.3 & 44.1 & 30.4 & 26.5 \\
\hline & 98.9 & $\mathrm{Ce}$ & & 84.8 & 78 & 87.2 & 58.2 & & 73.7 & 61.9 & 63.7 & 49.2 & 82.8 & 63.1 & 54.6 \\
\hline & 8.6 & $\mathrm{~Pb}$ & & 5.5 & 7.9 & 7.7 & 8 & & 10.1 & 8.2 & 6.2 & 6.3 & 7.9 & 9.4 & 7.5 \\
\hline & 45.4 & $\mathrm{Nd}$ & & 41.2 & 36.9 & 41.2 & 29.4 & & 33.3 & 30.2 & 30.8 & 24.3 & 39.5 & 29 & 26.2 \\
\hline & 7.4 & $\mathrm{Sm}$ & & 7.3 & 6.5 & 7 & 4.1 & & 5.8 & 5.1 & 4.8 & 4.3 & 6.1 & 5.9 & 4.9 \\
\hline & 100.1 & $\mathrm{Zr}$ & & 92.8 & 86.1 & 88.9 & 77 & & 98.6 & 77.3 & 70.6 & 66.8 & 83.1 & 82.5 & 72.3 \\
\hline & 1.8 & $\mathrm{Eu}$ & & 1.8 & 1.5 & 1.8 & 1.6 & & 1.4 & 1.4 & 1.5 & 1.2 & 1.4 & 1.4 & 1.2 \\
\hline & 4.5 & $\mathrm{Gd}$ & & 5.6 & 4 & 4.5 & 4.2 & & 3.9 & 3.8 & 3.3 & 3 & 4 & 4.2 & 3.1 \\
\hline & 3.3 & Dv & & 3 & 3.2 & 2.7 & 2.6 & & 2.9 & 2.6 & 2.5 & 2 & 1.8 & 2.6 & 2.4 \\
\hline & 0.8 & $\mathrm{Yb}$ & & 1.4 & 1.3 & 1.2 & 2.2 & & 1.6 & 1.5 & 1.4 & 1.1 & 1.7 & 1.2 & 1.5 \\
\hline & 11.3 & Th & & 8.9 & 8.8 & 9.7 & 6 & & 7.7 & 6.4 & 7.6 & 5.3 & 8.3 & 6.2 & 5.7 \\
\hline & 3.5 & U & & 3 & 2.8 & 3 & 1.9 & & 2.6 & 1.9 & 2.2 & 1.7 & 3.1 & 1.9 & 1.7 \\
\hline & 11.4 & $\operatorname{Pr}$ & & 9.7 & 9 & 10 & 6.8 & & 8.4 & 7.3 & 7.4 & 6 & 10.4 & 7.4 & 6 \\
\hline & 14 & $\mathrm{Y}$ & & 14 & 15.1 & 14 & 13.2 & & 15.1 & 13.5 & 12.2 & 11.6 & 14.5 & 14 & 12.3 \\
\hline & 0.2 & $\mathrm{Lu}$ & & 0.2 & 0.2 & 0.2 & $<0.182$ & & 0.2 & 0.2 & 0.2 & 0.2 & 0.3 & 0.2 & 0.2 \\
\hline \multirow{2}{*}{0.83} & 0.83 & Fo olivine & 0.83 & 0.83 & 0.83 & 0.83 & 0.84 & 0.84 & 0.85 & 0.84 & 0.84 & 0.83 & 0.83 & 0.85 & 0.84 \\
\hline & 2.00 & $\mathrm{Ne}$ & 0.5 & 3.59 & 7.23 & 8.55 & 3.69 & 4.28 & 5.56 & 4.97 & 4.67 & & 6.13 & 5.21 & 1.22 \\
\hline 3.09 & & Hy & & & & & & & & & & 18.03 & & & \\
\hline
\end{tabular}

and $\mathrm{Hy}$ are CIPW 
Table 1 continued

Puñalica volcano

\begin{tabular}{|c|c|c|c|c|c|c|c|c|c|c|c|c|c|c|c|c|}
\hline & & & & & & \multicolumn{11}{|c|}{ RIO17A } \\
\hline M1 & $\mathrm{N}$ & $\mathrm{O}$ & $\mathrm{P}$ & & Q & $\mathrm{R}$ & $\mathrm{S}$ & $\mathrm{S} 1$ & $\mathrm{~T}$ & $\mathrm{U}$ & U1 & $\mathrm{V}$ & $\mathrm{V} 2$ & $\mathrm{~W}$ & $\mathrm{X}$ & Y1 \\
\hline 49.54 & 48.18 & 48.87 & 49.38 & $\mathrm{SiO} 2$ & 50.34 & 49.98 & 51.43 & 54.12 & 53.73 & 51.65 & 50.74 & 53.73 & 51.46 & 45.26 & 50.39 & 48.19 \\
\hline 0.81 & 0.86 & 0.79 & 0.83 & $\mathrm{TiO} 2$ & 0.82 & 0.7 & 0.62 & 0.56 & 0.76 & 0.86 & 0.77 & 0.68 & 0.85 & 0.79 & 0.67 & 0.69 \\
\hline 16.53 & 16 & 16.21 & 17.19 & $\mathrm{~A} 12 \mathrm{O} 3$ & 17.72 & 16.01 & 17.57 & 16.55 & 18 & 18.23 & 17.65 & 17.51 & 17.2 & 15.06 & 17.31 & 16.43 \\
\hline 11.12 & 12.01 & 11.16 & 9.78 & $\mathrm{FeOt}$ & 9.65 & 11.06 & 8.3 & 7.77 & 6.36 & 7.14 & 8.38 & 7.39 & 9.62 & 15.08 & 9.13 & 13.16 \\
\hline 0.24 & 0 & 0.11 & 0.16 & $\mathrm{MnO}$ & 0.14 & 0.12 & 0.18 & 0.15 & 0.16 & 0.15 & 0.03 & 0.1 & 0.01 & 0.11 & 0.21 & 0.05 \\
\hline 7.86 & 8.81 & 8.44 & 7.09 & $\mathrm{MgO}$ & 6.78 & 7.27 & 5.69 & 5.34 & 4.64 & 5.45 & 6.37 & 5.33 & 6.89 & 10.2 & 6.57 & 8.4 \\
\hline 8.77 & 8.88 & 9.74 & 9.74 & $\mathrm{CaO}$ & 8.43 & 9.14 & 9.67 & 9.49 & 9.59 & 10.36 & 9.63 & 9.22 & 8.52 & 8.48 & 9.79 & 7.63 \\
\hline 3.6 & 3.52 & 3.12 & 4.06 & $\mathrm{Na} 2 \mathrm{O}$ & 4.25 & 3.81 & 4.37 & 3.97 & 4.54 & 4.07 & 4.3 & 4.19 & 3.76 & 3.34 & 4.02 & 3.68 \\
\hline 1.42 & 1.44 & 1.36 & 1.45 & $\mathrm{~K} 2 \mathrm{O}$ & 1.67 & 1.52 & 1.84 & 1.73 & 1.86 & 1.72 & 1.77 & 1.6 & 1.44 & 1.39 & 1.64 & 1.48 \\
\hline 0.12 & 0.3 & 0.19 & 0.31 & P2O5 & 0.21 & 0.39 & 0.33 & 0.31 & 0.35 & 0.38 & 0.36 & 0.25 & 0.26 & 0.29 & 0.27 & 0.29 \\
\hline \multirow[t]{3}{*}{97.69} & 95.57 & 95.23 & 98.79 & Total & 99.4 & 99.4 & 98.5 & 99.9 & 99.9 & 99.3 & 98.9 & 99.1 & 99.6 & 97.4 & 98.3 & 97.9 \\
\hline & 2.53 & 2 & & $\mathrm{H} 2 \mathrm{O}$ & 0.09 & 0.11 & & 0.08 & 0.13 & 0.11 & & 0.12 & 0.12 & & 0.28 & \\
\hline & 29 & 803 & & $\mathrm{CO} 2(\mathrm{ppm})$ & & 166 & 262 & 160 & 89 & 324 & & 101 & 860 & & 262 & \\
\hline $721^{b}$ & 793 & 593 & $673^{b}$ & $\mathrm{~F}(\mathrm{ppm})$ & 629 & 635 & 656 & 687 & 610 & 731 & $864^{b}$ & 700 & 712 & $923^{b}$ & 645 & $703^{b}$ \\
\hline $5678^{b}$ & 5849 & 4710 & $5430^{b}$ & $\mathrm{Cl}(\mathrm{ppm})$ & 4388 & 5548 & 4563 & 4265 & 4876 & 5796 & $6112^{b}$ & 5333 & 4123 & $5475^{b}$ & 5839 & $5449^{b}$ \\
\hline \multirow[t]{22}{*}{$4856^{b}$} & 6738 & 5020 & $3798^{b}$ & $\mathrm{~S}(\mathrm{ppm})$ & 1457 & 4009 & 3586 & 2310 & 2970 & 3282 & $3737^{b}$ & 2540 & 3165 & $3414^{b}$ & 4335 & $906^{b}$ \\
\hline & 21.3 & 20 & & $\mathrm{Sc}$ & 18.8 & 20.8 & 21.3 & 20.4 & 21.1 & 21.8 & & 15.8 & & & 20.5 & \\
\hline & $\begin{array}{l}292.3 \\
23.9\end{array}$ & $\begin{array}{l}214.3 \\
17.2\end{array}$ & & $\begin{array}{c}\mathrm{V} \\
\mathrm{Rb}\end{array}$ & $\begin{array}{c}209.3 \\
28\end{array}$ & $\begin{array}{r}175 \\
25.8\end{array}$ & $\begin{array}{l}174.2 \\
23.7\end{array}$ & $\begin{array}{c}183.9 \\
25.4\end{array}$ & $\begin{array}{l}190.7 \\
27.9\end{array}$ & $\begin{array}{l}209.4 \\
28.1\end{array}$ & & $\begin{array}{r}180 \\
23.7\end{array}$ & & & 178.7 & \\
\hline & 1168 & 1145.5 & & $\mathrm{Sr}$ & 1025.9 & 1184.7 & 1208.1 & 1249 & 1216.1 & 1224.6 & & 1088.3 & & & 1249.3 & \\
\hline & 3.3 & 2.9 & & $\mathrm{Nb}$ & 3.6 & 3.3 & 3.3 & 3.6 & 3.7 & 4 & & 3.2 & & & 3.5 & \\
\hline & 0.2 & 0.1 & & Ta & 0.2 & 0.2 & 0.2 & $<0.134$ & 0.2 & 0.2 & & 0.1 & & & 0.2 & \\
\hline & 579 & 502.6 & & $\mathrm{Ba}$ & 582.8 & 586.2 & 577.8 & 639.8 & 630.4 & 608.9 & & 587.6 & & & 602.2 & \\
\hline & 28 & 31.9 & & $\mathrm{La}$ & 24.2 & 27.7 & 36.5 & 37.5 & 25.7 & 29.7 & & 23.4 & & & 28.3 & \\
\hline & 56.4 & 63.7 & & $\mathrm{Ce}$ & 50.1 & 55.8 & 72 & 74.6 & 52.7 & 59.9 & & 51.6 & & & 59.2 & \\
\hline & 8.2 & 6.9 & & $\mathrm{~Pb}$ & 7.8 & 7.7 & 7.6 & 7.7 & 8.2 & 8.5 & & 9.6 & & & 8.3 & \\
\hline & 27.7 & 29.2 & & $\mathrm{Nd}$ & 23.8 & 27 & 34 & 34.9 & 25.8 & 28.9 & & 23.1 & & & 27.6 & \\
\hline & 5.2 & 5.2 & & $\mathrm{Sm}$ & 4.4 & 4.8 & 6 & 6.5 & 4.8 & 5 & & 4.3 & & & 4.8 & \\
\hline & 77.9 & 68.6 & & $\mathrm{Zr}$ & 86 & 80.5 & 85 & 89.2 & 83.8 & 90.1 & & 79.3 & & & 79.6 & \\
\hline & 1.3 & 1.4 & & $\mathrm{Eu}$ & 1.2 & 1.3 & 1.5 & 1.2 & 1.3 & 1.4 & & 1.4 & & & 1.5 & \\
\hline & 3.5 & 3.4 & & $\mathrm{Gd}$ & 3.1 & 3.3 & 3.9 & 4.5 & 3.3 & 3.6 & & 3 & & & 3 & \\
\hline & 2.6 & 2.5 & & Dv & 2.3 & 2.6 & 2.9 & 3.3 & 2.3 & 2.8 & & 1.9 & & & 2.7 & \\
\hline & 1.1 & 1.3 & & $\mathrm{Yb}$ & 1.2 & 1.4 & 1.5 & $i$ & 1.4 & 1.6 & & 0.8 & & & 1.3 & \\
\hline & 5.8 & 7.5 & & Th & 5.3 & 5.8 & 8.7 & 9.4 & 5.6 & 6.3 & & 5.1 & & & 6.1 & \\
\hline & 1.7 & 2.4 & & $\mathrm{U}$ & 1.7 & 1.8 & 2.7 & 3 & 1.8 & 2 & & 2 & & & 1.9 & \\
\hline & 6.8 & 7.4 & & $\operatorname{Pr}$ & 5.9 & 6.5 & 8.4 & 8.9 & 6.3 & 7 & & 6 & & & 6.9 & \\
\hline & 12.8 & 13.1 & & $\mathrm{Y}$ & 12.2 & 13.3 & 14.6 & 15.3 & 12.5 & 14.2 & & 11.3 & & & 12.8 & \\
\hline & 0.2 & 0.2 & & $\mathrm{Lu}$ & 0.2 & 0.2 & 0.3 & 0.2 & 0.2 & 0.2 & & 0.2 & & & 0.2 & \\
\hline 0.84 & 0.84 & 0.85 & 0.85 & Fo olivine & 0.85 & 0.84 & 0.84 & 0.84 & 0.85 & 0.86 & 0.86 & 0.85 & 0.85 & 0.84 & 0.85 & 0.83 \\
\hline 4.28 & 6.18 & 3.84 & 7.23 & $\begin{array}{l}\mathrm{Ne} \\
\mathrm{Hy}\end{array}$ & 6.29 & 4.79 & 6.96 & 1.28 & 3.39 & 4.82 & 7.42 & 0.60 & 0.79 & 10.10 & 6.62 & 5.45 \\
\hline
\end{tabular}




\section{CAR83A}

\begin{tabular}{|c|c|c|c|c|}
\hline & \multicolumn{4}{|c|}{ CAR83A } \\
\hline Z & BA & BB & $\mathrm{BC}^{*}$ & BD1 \\
\hline 52.87 & 54.59 & 54.29 & 53.51 & 55.25 \\
\hline 0.81 & 0.84 & 1.05 & 0.91 & 0.98 \\
\hline 18.02 & 18.97 & 19.7 & 18.77 & 18.66 \\
\hline 6.97 & 6.18 & 5.43 & 7.14 & 5.58 \\
\hline 0.07 & 0.07 & 0.24 & 0.1 & 0.07 \\
\hline 5.3 & 4.28 & 3.99 & 4.97 & 3.94 \\
\hline 9.8 & 8.59 & 9.35 & 8.18 & 8.21 \\
\hline 4.32 & 4.85 & 4.27 & 4.67 & 5.26 \\
\hline 1.7 & 1.5 & 1.38 & 1.43 & 1.86 \\
\hline 0.15 & 0.14 & 0.3 & 0.32 & 0.18 \\
\hline 99 & $\begin{array}{c}101.6 \\
0.06 \\
51\end{array}$ & 99.6 & 100.6 & $\begin{array}{c}102.2 \\
0.11 \\
4307\end{array}$ \\
\hline $1008^{b}$ & 439 & $558^{\mathrm{b}}$ & $533^{b}$ & 504 \\
\hline $5717^{b}$ & 1533 & 1625 & $1352^{b}$ & 1948 \\
\hline $2829^{b}$ & 1571 & 609 & $1248^{b}$ & 1562 \\
\hline & 21.4 & & 17.6 & 16.6 \\
\hline & 205.4 & & 180.4 & 201.6 \\
\hline & 29.9 & & $\begin{array}{l}28.6 \\
5626\end{array}$ & $\begin{array}{c}33.8 \\
5848\end{array}$ \\
\hline & $\begin{array}{c}584.6 \\
4\end{array}$ & & $\begin{array}{c}562.6 \\
3.6\end{array}$ & $\begin{array}{c}584.8 \\
4.1\end{array}$ \\
\hline & $<0.211$ & & 0.3 & 0.3 \\
\hline & 483 & & 453.8 & 597.1 \\
\hline & 12.1 & & $\begin{array}{l}11.4 \\
25.7\end{array}$ & 12.7 \\
\hline & 7.9 & & 5.9 & $\begin{array}{l}29.1 \\
7.4\end{array}$ \\
\hline & 13.5 & & 13.9 & 13.9 \\
\hline & 2.9 & & 2.3 & 4.2 \\
\hline & $\begin{array}{l}88.8 \\
0.9\end{array}$ & & $\begin{array}{l}83 \\
0.9\end{array}$ & $\begin{array}{r}89.3 \\
0.9\end{array}$ \\
\hline & 3.6 & & 2.3 & 2 \\
\hline & 2.9 & & 2.2 & 2.6 \\
\hline & 1.5 & & 0.6 & 0.9 \\
\hline & 2.8 & & 2.8 & 3.1 \\
\hline & 1.1 & & 1 & 1.2 \\
\hline & 3.6 & & 3.2 & 3.4 \\
\hline & 11.5 & & 10.3 & 10.6 \\
\hline & 0.2 & & 0.1 & $<0.19$ \\
\hline 0.86 & 0.83 & 0.84 & 0.83 & 0.84 \\
\hline 4.08 & 1.32 & & 0.94 & 3.03 \\
\hline & & 5.78 & & \\
\hline
\end{tabular}


Table 2 New whole-rock data from Puñalica volcano. The remaining whole-rock data for Puñalica are from Schiano et al. (2010). All Sangay whole-ror used in this paper are from Monzier et al. (1999). SAN20B whole-rock sample is shown for reference.

\begin{tabular}{|c|c|c|c|c|c|c|c|c|c|c|c|c|c|c|c|c|}
\hline & \multicolumn{16}{|c|}{ Puñalica volcano } \\
\hline & RI017A & $\begin{array}{l}\text { RIO } \\
18 b i s\end{array}$ & $\begin{array}{c}\text { RIO } \\
\text { 20bis }\end{array}$ & $\begin{array}{c}\text { CAR- } \\
01 \mathrm{~F}\end{array}$ & $\begin{array}{c}\text { CAR- } \\
09 \mathrm{G}\end{array}$ & CAR-09J & $\begin{array}{l}\text { CAR- } \\
13 \mathrm{~F}\end{array}$ & $\begin{array}{c}\text { CAR- } \\
26 \mathrm{C}\end{array}$ & $\begin{array}{c}\text { CAR- } \\
59 A\end{array}$ & $\begin{array}{l}\text { CAR- } \\
59 B\end{array}$ & $\begin{array}{l}\text { CAR- } \\
59 \mathrm{~B} \text { bis }\end{array}$ & $\begin{array}{c}\text { CAR- } \\
\text { 59D }\end{array}$ & CAR-71 & $\begin{array}{c}\text { CAR } \\
79 A\end{array}$ & CAR 80 & $\begin{array}{l}\text { CAR } \\
83 A\end{array}$ \\
\hline $\mathrm{SiO} 2$ & 56.55 & 54.98 & 56.72 & 55.60 & 59.48 & 55.73 & 56.19 & 58.27 & 58.60 & 55.22 & 55.13 & 59.68 & 55.11 & 56.01 & 58.27 & 58.36 \\
\hline $\mathrm{TiO} 2$ & 0.74 & 0.76 & 0.75 & 1.04 & 0.78 & 1.04 & 0.92 & 0.85 & 0.78 & 0.75 & 0.74 & 0.75 & 0.80 & 0.75 & 0.76 & 0.76 \\
\hline $\mathrm{Al} 2 \mathrm{O} 3$ & 14.85 & 16.23 & 15.47 & 17.96 & 16.97 & 17.87 & 17.23 & 16.26 & 17.19 & 16.78 & 16.77 & 16.29 & 17.30 & 15.46 & 15.63 & 15.59 \\
\hline $\mathrm{FeOt}$ & 7.14 & 7.38 & 7.01 & 7.44 & 5.96 & 7.55 & 7.18 & 6.55 & 6.47 & 7.22 & 7.19 & 6.15 & 7.44 & 7.10 & 6.72 & 6.64 \\
\hline $\mathrm{MnO}$ & 0.12 & 0.12 & 0.11 & 0.13 & 0.10 & 0.13 & 0.12 & 0.11 & 0.10 & 0.14 & 0.14 & 0.10 & 0.14 & 0.13 & 0.11 & 0.11 \\
\hline $\mathrm{MgO}$ & 7.48 & 6.02 & 6.99 & 4.53 & 3.80 & 4.33 & 5.24 & 5.51 & 4.96 & 5.84 & 5.82 & 4.84 & 4.92 & 7.10 & 6.31 & 6.21 \\
\hline $\mathrm{CaO}$ & 8.24 & 9.22 & 7.87 & 7.59 & 6.34 & 7.76 & 8.10 & 6.82 & 6.63 & 8.54 & 8.59 & 6.57 & 8.94 & 8.45 & 7.23 & 7.22 \\
\hline $\mathrm{Na} 2 \mathrm{O}$ & 3.41 & 3.58 & 3.68 & 3.89 & 4.44 & 3.77 & 3.77 & 4.03 & 3.86 & 3.69 & 3.75 & 3.99 & 3.79 & 3.49 & 3.69 & 3.77 \\
\hline $\mathrm{K} 2 \mathrm{O}$ & 1.26 & 1.45 & 1.21 & 1.59 & 1.89 & 1.57 & 1.01 & 1.40 & 1.20 & 1.55 & 1.62 & 1.42 & 1.34 & 1.31 & 1.11 & 1.17 \\
\hline $\mathrm{P} 2 \mathrm{O} 5$ & 0.21 & 0.25 & 0.20 & 0.24 & 0.24 & 0.26 & 0.24 & 0.21 & 0.21 & 0.26 & 0.25 & 0.20 & 0.22 & 0.20 & 0.18 & 0.17 \\
\hline Total & 99.65 & 99.56 & 99.41 & 100.12 & 100.06 & 100.10 & 99.37 & 100.41 & 100.05 & 100.47 & 100.04 & 99.35 & 100.96 & 99.90 & 99.98 & 100.14 \\
\hline $\mathrm{Sc}$ & 20.20 & 25.68 & 19.89 & 18.61 & 14.55 & 18.62 & 24.06 & 17.19 & 15.84 & 23.68 & 24.17 & 15.57 & 25.55 & 23.69 & 20.09 & 19.41 \\
\hline $\mathrm{V}$ & 184.00 & 211.44 & 185.91 & 206.76 & 160.92 & 208.94 & 208.03 & 173.05 & 159.84 & 203.50 & 196.73 & 159.22 & 226.67 & 190.40 & 172.09 & 172.74 \\
\hline $\mathrm{Rb}$ & 21.50 & 19.35 & 18.69 & 39.09 & 36.44 & 37.71 & & 27.35 & 31.03 & 21.45 & 30.19 & 38.48 & 25.92 & 23.44 & 21.54 & 23.53 \\
\hline $\mathrm{Sr}$ & 910.00 & 1140.35 & 857.69 & 617.35 & 636.47 & 599.76 & 718.00 & 629.20 & 671.40 & 1136.62 & 1158.32 & 636.99 & 1133.55 & 922.83 & 547.22 & 558.13 \\
\hline $\mathrm{Nb}$ & 3.40 & 4.31 & 4.11 & 5.95 & 5.36 & 6.12 & & 4.46 & 3.94 & 3.95 & 4.07 & 3.94 & 3.55 & 3.70 & 3.61 & 4.45 \\
\hline $\mathrm{Ba}$ & 525.00 & 612.44 & 488.73 & 688.48 & 857.12 & 738.29 & 472.00 & 592.16 & 632.32 & 660.61 & 665.55 & 601.98 & 551.44 & 546.09 & 415.31 & 442.94 \\
\hline $\mathrm{La}$ & 20.50 & 33.68 & 19.23 & 16.42 & 16.30 & 15.16 & & 16.74 & 20.52 & 34.43 & 33.88 & 20.24 & 21.61 & 21.93 & 11.72 & 12.41 \\
\hline $\mathrm{Ce}$ & 43.00 & 65.31 & 36.77 & 32.19 & 33.12 & 33.26 & & 33.28 & 40.02 & 65.91 & 65.07 & 37.31 & 42.71 & 43.41 & 25.13 & 25.56 \\
\hline $\mathrm{Nd}$ & 22.00 & 31.30 & 19.58 & 18.76 & 17.09 & 18.13 & & 17.26 & 21.29 & 32.36 & 32.41 & 20.53 & 23.22 & 22.34 & 13.69 & 13.87 \\
\hline $\mathrm{Sm}$ & 4.35 & 5.72 & 3.71 & 4.24 & 3.52 & 4.12 & & 3.82 & 3.81 & 5.56 & 5.75 & 3.78 & 4.30 & 4.29 & 2.98 & 2.97 \\
\hline $\mathrm{Zr}$ & 95.00 & 97.50 & 93.38 & 120.92 & 122.20 & 126.08 & 106.73 & 102.97 & 105.47 & 93.38 & 88.33 & 100.92 & 88.13 & 95.21 & 94.43 & 98.07 \\
\hline $\mathrm{Eu}$ & 1.15 & 1.46 & 1.17 & 1.17 & 0.97 & 1.17 & & 1.00 & 1.11 & 1.48 & 1.51 & 1.11 & 1.22 & 1.25 & 0.86 & 0.92 \\
\hline $\mathrm{Gd}$ & 3.50 & 3.93 & 2.85 & 4.16 & 2.93 & 3.77 & & 3.37 & 3.46 & 4.16 & 4.01 & 3.12 & 3.58 & 3.28 & 2.61 & 2.78 \\
\hline Dy & 2.45 & 2.96 & 2.38 & 3.19 & 2.29 & 2.93 & & 2.16 & 2.12 & 2.94 & 2.92 & 2.13 & 2.86 & 2.57 & 2.29 & 2.30 \\
\hline $\mathrm{Yb}$ & 1.24 & 1.60 & 1.13 & 1.58 & 1.19 & 1.55 & & 1.04 & 0.89 & 1.58 & 1.61 & 0.89 & 1.63 & 1.33 & 1.07 & 1.12 \\
\hline Th & 4.40 & 7.75 & 4.28 & 4.57 & 3.73 & 3.42 & & 4.23 & 6.10 & 7.68 & 7.73 & 5.62 & 4.07 & 5.11 & 3.06 & 3.15 \\
\hline $\mathrm{Y}$ & 12.90 & 17.12 & 12.82 & 18.03 & 13.59 & 18.29 & 16.35 & 12.06 & 10.62 & 16.60 & 16.76 & 10.85 & 17.54 & 14.62 & 12.16 & 12.83 \\
\hline
\end{tabular}


Table 2 continued

Puñalica volcano

\begin{tabular}{|c|c|c|c|c|c|c|c|c|c|c|c|c|}
\hline CAR-87 & & CAR-113B & CAR-88 & CAR-89 & CAR-96A & CAR-97 & CAR-98 & CAR-100 & CAR-102 & CAR-107 & CAR-112 & CAR-114A \\
\hline 58.13 & $\mathrm{SiO} 2$ & 54.91 & 58.38 & 54.64 & 55.03 & 55.20 & 56.65 & 55.02 & 54.79 & 55.26 & 54.55 & 54.85 \\
\hline 0.83 & $\mathrm{TiO} 2$ & 0.74 & 0.82 & 0.72 & 0.71 & 0.72 & 0.78 & 0.72 & 0.79 & 0.78 & 0.79 & 0.79 \\
\hline 16.33 & $\mathrm{~A} 12 \mathrm{O} 3$ & 15.88 & 16.39 & 15.35 & 15.52 & 15.61 & 16.28 & 15.81 & 17.39 & 17.65 & 17.35 & 17.32 \\
\hline 6.82 & $\mathrm{FeOt}$ & 7.51 & 6.80 & 7.51 & 7.52 & 7.46 & 7.11 & 7.37 & 7.67 & 7.76 & 7.90 & 7.82 \\
\hline 0.11 & $\mathrm{MnO}$ & 0.14 & 0.10 & 0.14 & 0.14 & 0.14 & 0.12 & 0.13 & 0.14 & 0.14 & 0.14 & 0.14 \\
\hline 5.43 & $\mathrm{MgO}$ & 6.70 & 5.11 & 7.17 & 6.51 & 6.77 & 5.74 & 6.56 & 4.92 & 4.47 & 4.93 & 4.98 \\
\hline 3.90 & $\mathrm{Na} 2 \mathrm{O}$ & 3.45 & 3.96 & 3.34 & 3.34 & 3.48 & 3.77 & 3.48 & 3.62 & 3.83 & 3.72 & 3.60 \\
\hline 1.36 & $\mathrm{~K} 2 \mathrm{O}$ & 1.40 & 1.34 & 1.38 & 1.40 & 1.38 & 1.20 & 1.42 & 1.25 & 1.28 & 1.24 & 1.26 \\
\hline 0.22 & $\mathrm{P} 2 \mathrm{O} 5$ & 0.23 & 0.21 & 0.24 & 0.25 & 0.23 & 0.21 & 0.23 & 0.23 & 0.23 & 0.23 & 0.19 \\
\hline 100.28 & Total & 98.71 & 99.92 & 98.69 & 98.19 & 98.61 & 97.55 & 98.64 & 100.30 & 99.14 & 98.08 & 99.85 \\
\hline 16.61 & $\mathrm{Sc}$ & 25.27 & 16.27 & 27.30 & 27.45 & 25.27 & 19.52 & 25.42 & 25.72 & 23.53 & 25.49 & 25.73 \\
\hline 167.83 & $\mathrm{~V}$ & 197.99 & 173.85 & 211.53 & 214.44 & 202.29 & 182.59 & 208.71 & 219.77 & 213.74 & 221.29 & 221.47 \\
\hline 24.51 & $\mathrm{Rb}$ & 18.95 & 24.99 & 17.26 & 16.57 & 19.01 & 17.26 & 19.77 & 13.92 & 15.22 & 14.80 & 14.51 \\
\hline 635.41 & $\mathrm{Sr}$ & 1078.28 & 591.80 & 1041.79 & 1043.17 & 1061.88 & 801.35 & 1083.97 & 1093.99 & 1098.95 & 1066.35 & 1091.83 \\
\hline 15.27 & $\mathrm{La}$ & 26.30 & 14.59 & 30.30 & 33.99 & 26.93 & 17.34 & 27.78 & 19.86 & 20.06 & 19.29 & 20.37 \\
\hline 31.57 & $\mathrm{Ce}$ & 51.56 & 29.30 & 57.73 & 65.04 & 51.93 & 36.54 & 53.56 & 37.25 & 36.21 & 39.07 & 37.10 \\
\hline 16.91 & $\mathrm{Nd}$ & 26.35 & 16.31 & 28.99 & 31.71 & 26.22 & 19.11 & 26.91 & 21.04 & 21.52 & 21.25 & 20.98 \\
\hline 3.92 & $\mathrm{Sm}$ & 4.70 & 3.50 & 6.00 & 5.65 & 5.18 & 4.13 & 5.24 & 3.99 & 4.48 & 4.40 & 4.40 \\
\hline 110.55 & $\mathrm{Zr}$ & 93.26 & 115.19 & 104.79 & 100.71 & 98.39 & 95.27 & 98.30 & 104.15 & 98.28 & 97.84 & 101.02 \\
\hline 1.09 & $\mathrm{Eu}$ & 1.30 & 0.95 & 1.42 & 1.49 & 1.24 & 1.09 & 1.28 & 1.21 & 1.18 & 1.09 & 1.18 \\
\hline 3.36 & $\mathrm{Gd}$ & 3.87 & 3.29 & 3.90 & 4.28 & 3.71 & 3.72 & 3.86 & 3.54 & 3.78 & 3.90 & 3.54 \\
\hline 2.32 & Dy & 2.71 & 2.43 & 3.04 & 3.02 & 2.82 & 2.60 & 2.81 & 3.00 & 3.07 & 2.96 & 3.14 \\
\hline 1.05 & $\mathrm{Yb}$ & 1.48 & 1.00 & 1.54 & 1.57 & 1.51 & 1.20 & 1.52 & 1.61 & 1.72 & 1.69 & 1.57 \\
\hline 4.11 & Th & 5.78 & 3.44 & 7.06 & 8.16 & 5.83 & 3.73 & 5.83 & 3.72 & 3.85 & 3.69 & 4.18 \\
\hline 12.12 & $\mathrm{Y}$ & 16.09 & 12.01 & 15.96 & 16.70 & 15.63 & 13.53 & 16.05 & 16.66 & 17.97 & 17.20 & 15.97 \\
\hline
\end{tabular}




\begin{tabular}{|c}
\hline Sangay volcano \\
\hline SAN20B \\
\hline 50.28 \\
1.01 \\
14.80 \\
8.71 \\
0.15 \\
11.12 \\
8.92 \\
3.34 \\
1.32 \\
0.34 \\
98.78 \\
24.00 \\
220.00 \\
25.00 \\
970.00 \\
9.00 \\
644.00 \\
19.20 \\
39.00 \\
22.40 \\
91.00 \\
1.26 \\
3.50 \\
2.76 \\
1.24 \\
3.50 \\
14.90 \\
\hline
\end{tabular}

